Lale Güremen

Amasya University, lguremen@gmail.com, Amasya-Turkey

http://dx.doi.org/10.12739/NWSA.2014.9.4.1A0353

\title{
AMASYA KENT MERKEZİ ANA ARTER YOLLARINDA TRAFİK GÜRÜLTÜSÜNÜN TRAFİK KOŞUL VE STANDARTLARI YÖNÜYLE DEĞERLENDİRİLMESİ
}

\section{ÖZET}

Trafik, kentsel alanlarda çevresel gürültü kirliliğinin baskın kaynağıdır. Bu çalışma, Amasya kent merkezinde trafikten kaynaklanan çevresel gürültü kirliliği ile ilgili bir araştırmanın sonuçları olarak sunulmuştur. Çalışma kent merkezinde trafik yoğunluğunu üzerinde taşıyan ana arter ve yollarında 54 ayrı noktada gürültü kirliliğinin ana indeksleri (Leq, LNP, TNI, L10, L50, L90) ve trafik akışı ve kompozisyonu geniş kapsamlı ölçümlere ve değerlendirmelerine göre yürütülmüştür. Ölçüm ve değerlendirmeler sonucunda, Kent merkezindeki trafik akışının yoğun olduğu ana arter ve alternatif yollarında günlük ölçüm süresi içerisinde gürültü düzeyi; standartlarla belirlenmiş ortalama düzeyin 10 dBA üzerine çıkmıştır. Trafikten kaynaklanan gürültü düzeyi; o yerleşime has mekânsal yapıya, coğrafi, jeo morfolojik yapıya ve ulaşım altyapısına bağlıdır.

Anahtar Kelimeler: Trafik Gürültüsü, Taşıt Yoğunluğu, Trafik Gürültü Kirliliği, Amasya

\section{EVALUATION OF TRAFFIC NOISE ON THE MAIN ROADS OF AMASYA CITY CENTER WITH RESPECT TO TRAFFIC CONDITIONS AND STANDARTS}

\section{ABSTRACT}

Traffic is the dominant source of environmental noise pollution in urban areas. This study presents a research on noise pollution created from traffic in Amasya City Center. The research is conducted on the main roads which are the source of noise pollution referring to the results of the 54 different measurement points with main noise indexes (Leq, LNP, TNI, L10, L50, L90) due to main traffic flow. As a result of measurements and evaluation, it is determined that noise level in the main and alternative routes exceeds the standard level of noise with the value of about 10 dBA within the daily measurement time. It is determined that, traffic sourced environmental noise pollution is related with sui generis spatial structure, geographical and geo morphological structure and transportation infrastructure of the city.

Keywords: Traffic Noise, Vehicle Density, Traffic Noise Index, Amasya City Center, Noise Pollution 


\section{GIRIŞ (INTRODUCTION)}

Gürültü önemli bir çevre kirleticisi olduğu kadar bir halk sağlığı sorunudur. Çevre kalitesini düşürür ve insan sağlığını olumsuz yönde etkilemektedir. Diğer fiziksel çevre faktörlerinin (elektromanyetik alanlar veya hava kirleticiler) aksine, gürültü; insanlarda işitsel sistem tarafından algllanır. Bu nedenle hissedilen ve herkes tarafından değerlendirilebilir yaşam kalitesini etkileyen bir olgudur. Özellikle kentlerde yaşayan nüfusun yaşam çevrelerini olumsuz yönde etkileyen en sık belirtilen gürültü kaynağı trafikten kaynaklanan gürültüdür. Tamamen ortadan kaldırılmasa da azaltılması mümkündür [1]. Ulaşımdan kaynaklanan yol trafik gürültüsü; otoyolların çoğalması, trafikteki hızlı artışlar, yoğunlaşmalar ve yüksek düzeyli olmaları, çok sayıda kişiyi etkilemeleri, kent ölçeğinde inceleme zorunluluğu ve getirilecek çözümler için planlama ölçeğinden başlayarak stratejik ve politik kararları gerektirmesi nedeniyle önem taşımaktadır [2].

Çevre konusunda kanun ve mevzuatlar uluslararası boyutta önem kazanmaktadır, özellikle çevre gürültüsü konusunda ulusal ve uluslararası verileri karşılaştırmak ve değerlendirmek daha önemli hale gelmiştir. Bu nedenle gürültü endeksi ve standartları üzerinde gürültü etkilenme sonuçlarını karşılaştırmak önemli ölçüde daha da zorlaşmaktadır. Bu nedenle yerel düzeydeki Gürültü endeks ve standartlarındaki uyum konusunda Avrupa Komisyonu tarafından öngörülen gürültü standartları ve endeksleri gürültü düzeylerinin belirlenmesinde önemli olmuştur. Her ne kadar gürültü standartları üye ülkelerin kendilerine bırakılmış olsa da, LAE Endeksine uyumlu gürültü seviyesi hesaplamaları tavsiye olunmuştur. Bu noktadan hareketle yapılan birçok çalışmanın bulguları incelendiğinde gürültünün denetim altına alınması gerekliliğini ortaya koymuştur. Bu çerçevede kabul edilebilecek ses koşullarına ilişkin ölçüt ve önlem önerileri geliştirilmiş, bunların uygulanmaları sağlanmıştır [3] .

Nas, (2009), Konya kenti yerleşim alanında gürültü kirliliği haritasının yapılması amacıyla yaklaşık $120 \mathrm{~km}^{2}$ 'lik alanı kapsayan trafiğin yoğun olduğu kavşaklar ve ana yollar üzerinde 189 ayrı noktada ölçüm çalışması yapmıştır [4]. Aydın ve Ateş (1997), Konya'da trafik gürültüsü konusunda yapmış oldukları bir araştırmanın sonuçlarına göre araştırma kapsamı içindeki bölgelerde bütün gürültü seviyelerinin yönetmelikte öngörülen seviyelerin üzerinde olduğunu gözlemlemişlerdir. Söz konusu bölgelerde gürültü seviyesinin azaltılması için bazı tedbirlerin alınması gerekliliğini önerilmişlerdir [5]. Gezbul ve Öz, (1996), Adapazarı'nda önemli rolü bulunan ve ana trafik akımlarının olduğu kıyıya paralel bulvar ve caddeler, bu caddeler arasında bağlantıyı sağlayan önemli kavşaklar ve trafik akımlarının içinde yer alan meydanlarda belirledikleri 22 istasyonda trafik gürültüsünü ölçmüşlerdir. Bu ölçüm ve değerlendirmeler sonucunda 70 dBA'yı aşan düzeyleri belirlemişlerdir [6]. Özer ve Yeşil, (2009), Tokat şehir merkezinde otoyol gürültü seviyelerini belirlemek amacıyla 65 noktada akşam 17-19 saatleri arasında yaptıkları ölçümlerde birçok noktada ülkemiz için yönetmelikle belirlenmiş olan Leq 65 dBA'nın aşılmış olduğunu belirlemişlerdir [7].

Kemalettin, (2012), Atakum (Samsun) şehrin de gürültü kirliliğinin kaynaklarını tespit etmek amacıyla çevresel gürültü ölçümleri yapmışır [8]. Piccolo, Plutino, nve Cannistraro İtalya'nın Messina Kentinde çevresel gürültü kirliliği kaynağı kapsamında trafik gürültüsünü değerlendirmişlerdir. Bu çalışmalarında, kentin önemli trafik yol ve kavşakları üzerinde yer alan 35 yerleşim noktasında trafik akım ve kompozisyonları ile bu yollar üzerinde gürültü ölçümleri yaparak L10, L50, L90 ve Leq seviyelerini belirlemişlerdir. 
Elde edilen bulgulara göre günlük ortalama ses seviyelerinin standartlarda saptanmış olan düzeylerin o25 üzerinde olduğu belirlenmiştir. Bu yüksek düzeylerin şehrin yer aldığı coğrafi bölgenin jeo-morfolojik yapısı ulaşım alt yapı verilerine bağlı olduğu sonucuna varmışlardır [9].

GBluhm ve diğerleri,(2006), stockholm kentinde artan trafik gürültüsünün önemli bir çevre sorunu olduğunu, kentsel yerleşim alanlarında yoğun trafik artışı ve neden olduğu gürültüden bu alanlarda yaşayanların duymuş oldukları rahatsızlığın belirlenmesi için yaptıkları çalışmalarında ölçtükleri Leq 50-55 dBA seviyelerinin uyku kalitesini ne ölçüde etkilediğinin belirlenmesi için 19-80 yaşlarında 1000 kişi üzerinde anket çalışması yapmış ve elde ettikleri sonuçlara göre gürültünün düşük seviyelerde olsa bile uyku kalitesini bozduğu, uykuyu böldüğü ve uyuyamama sıkıntılarını tespit etmiştir [10].

Bendtsen, (1999), Danimarka uluslararası transit karayolu için yaptığı çalışmasında gürültü denetimi için uygulanabilir bir yöntem ve aynı zamanda gürültü azaltılması için mevcut karayollarında gürültü sorunlarını azaltmak için arazi planlaması ve binalarda dış cephelerinde alınacak önlemlerle trafikten kaynaklanan gürültünün azaltılması konusunda uygun stratejiler sunar bunun için kamu-özel sektör desteğinin gerekliliğini öngörmektedir [11] .

Güremen ve Çelik, (2002), Niğde Kent Merkez'inde seçilen 11 bölgede 61 referans noktasında haftanın farklı günleri ve zamanlarına göre L10, L50, L90, Leq, TNI, LNP ve Lmax düzeylerini ölçerek, sonuçlarını standart gürültü düzeyleri sınır değerleri ile karşılaştırarak değerlendirmişlerdir [12].

Bütün bu araştırma ve literatür incelemeleri ışığında Amasya kenti merkezinde ana arter ve yolları ile bu yollara yakın belirlenen yerleşim bölgelerinde trafikten kaynaklanan gürültünün ölçüm ve değerlendirmeleri sonuçlarından elde edilen bulgular ile, dünyadaki çeşitıi kentler için yapılmış bu tür araştırmaların sonuçları karşılaştırılarak Amasya'nın kent merkezindeki gürültü kirliliği açısından değerlendirmeler yapılması mümkün olabilecektir.

\section{2. ÇALIŞMANIN ÖNEMİ (RESEARCH SIGNIFICANCE)}

Amasya kent merkezinde yapılan bu çalışma; kentin anayollarında belirlenen noktalarda gürültü ölçüm ve analizlerine dayalı taşıt trafiğinden kaynaklanan gürültünün standartlarca belirlenmiş olan düzeylerle uyumlu olup olmadığının ortaya konulmasını amaçlamaktadır. Ölçüm yapılan bölgelerde saptanan L10, L50, L90 ve Leq değerleri farklı çalışmalarda belirtilen gürültü düzeyleri ile de karşılaştırılmıştır. Amasya'da seçilmiş bölgeler içerisinden veya yakınından geçen trafik yollarına ait gürültü indislerinin kabul edilmiş olan L10, L50, L90 ve Leq ölçüt değerleri ile karşılaştırması yapılarak, incelenen bölgelerde birimlere göre değişen kriterlerin veya sınır değerlerinin aşıldığı durumlar veya çelişkilerin ortaya konulması, bu araştırmanın amaçları arasında olup, bunun için istatistiksel gürültü düzeylerinin ağırlıklı olarak birleştirildiği TNI(Traffic Noise Index) değerleri araştırılmıştır. Bu sonuçlardan yararlanılarak, ülkemiz için dış çevre gürültüsü standartları olarak önerilebilecek gürültü denetimi ölçütleri gözden geçirilebilecektir.

Çalışma toplumun sağlığı üzerinde etkileri giderek artan gürültü konusunu Amasya Kenti özelinde ele alarak kent içi trafik gürültüsünü ortaya koyması yönüyle önem taşımaktadır. Gürültü kirliliği ve tehlikeleri konusunda toplumun bilinçlendirilmesi gerekmektedir. Kirlilik sorunlarının tümünde olduğu gibi, sorunun çözümü eğitim ve yönetimden geçmektedir. Daha temiz ve sağlıklı bir kent yaşamının oluşturulması için bu konuda yapılacak bilimsel araştırmaların 
arttırılması akademik çevreler ve yerel yönetimlerce desteklenmesi önem taşımaktadır.

Bu çalışma için önemli olan bir diğer husus ise; bu araştırmanın sonuçlarının daha sonra yapılacak çeşitli çevre ölçeklerinde (şehir planlaması, bina planlaması ve yapı elemanları planlaması)gürültü kontrolü ve yapısal standartlar konularında ki çalışmalar için temel olacağı düşünülmektedir.

\section{MATEYAL VE YÖNTEM (MATERIAL AND METHOD)}

Saha çalışmasında ölçmeler, RION NL-21 (Sound Level Meter) gürültü seviyesi ölçüm cihazı ve cihazla entegre edilebilen ekipmanlardan oluşan bir düzenek ile gerçekleştirilmiştir. Düzenek: EC-04 Serisi Mikrofon kablosu, CF Compact Flash Card ve Tripottan oluşmaktadır. Cihazın kalibrasyonu, dahili Kalibre fonksiyonu ile yapılmıştır. Nl-21 Gürültü ölçüm cihazı LAE, LAeq, LAMax, LAmin, L1710, LA50, LA90, LA95, Lcpk seviyelerinde ölçümler yapabilmektedir. Trafik gürültüsü ölçümleri, her bölgede tespit edilen 54 Referans noktasında yoldan en az 1- 2.5 metre içeride gerçekleştirilmiştir. Bu referans noktalarının seçiminde arkasında binalar dış duvarlarından 1 metre uzaklıkta bulunan zeminden etkilenmemesi için standartlarda belirtilen ve birçok araştırmacı tarafından kabul gören $1.50 \mathrm{~m}$. Yükseklikte olan gürültünün yansıma ve saçılmalara uğramadan direkt olarak mikrofona ulaşabilmesi içinde balkon saçak ve diğer pürüzlülüklerin bulunmamasına dikkat edilmiștir. Belirlenen noktalarda ön çalışmalar sonucunda kent içi trafik gürültüsü ölçümlerinde, haftanın günlerine, günlerin saatlerine göre hatta trafik akım ve yoğunluğuna bağlı olarak değişim gösterdiği gözlenmiştir. Bu durumlarda bazı araştırmalarda $24 \mathrm{~h}$ ve $18 \mathrm{~h}$ boyunca ölçümleri gerçekleştirilmiştir [14 ve 15]. Zannin, P.H.T. ve arkadaşları, Brezilya'nın Curitiba kentinde Leg ölçümlerinde gün/lsaat' uygun bulmuştur [16].

\section{BULGULAR (RESULTS)}

Kent, güney-batı kuzey-doğu doğrultulu doğrusal (lineer) bir kentsel makroform biçiminde gelişmiştir. Kent; bu özellikleriyle beraber güney-batı kuzey-doğu doğrultulu doğrusal (lineer) bir kentsel makroform içinde gelişmiştir. Amasya kentinin bu formunun temel belirleyicilerinden biri Yeşilırmak nehri olup, kenti çevreleyen tepeler de, doğrusal makroformun oluşmasında bir diğer faktör olarak karşımıza çıkmaktadır. Kentin bu makroformu, kent içi yolların ve trafiğinin alternatifli oluşmasını engellemiştir. Kent, Yeşilırmağın her iki yanında yaklaşık 7-8 kilometre boyunca uzanmaktadır (şekil 1). Kent trafiği Mustafa Kemal Paşa Caddesi, Atatürk Caddesi ve Mehmet Varinli Caddeleri ile alternatifi olarak Yeşilırmak boyunca uzanan Ziya Paşa Bulvarı ve Mehmet Paşa Caddelerinde yoğunlaşmaktadır. Kent makroformunun her iki yanında bulunan tepeler; kentin doğrusal oluşumunda büyük rol oynamış olup, kent içi yollarının ve trafiğinin alternatifli oluşmasını engellemiştir. Şehirlerarası D-100 karayolu kentin tam ortasından geçmektedir. 


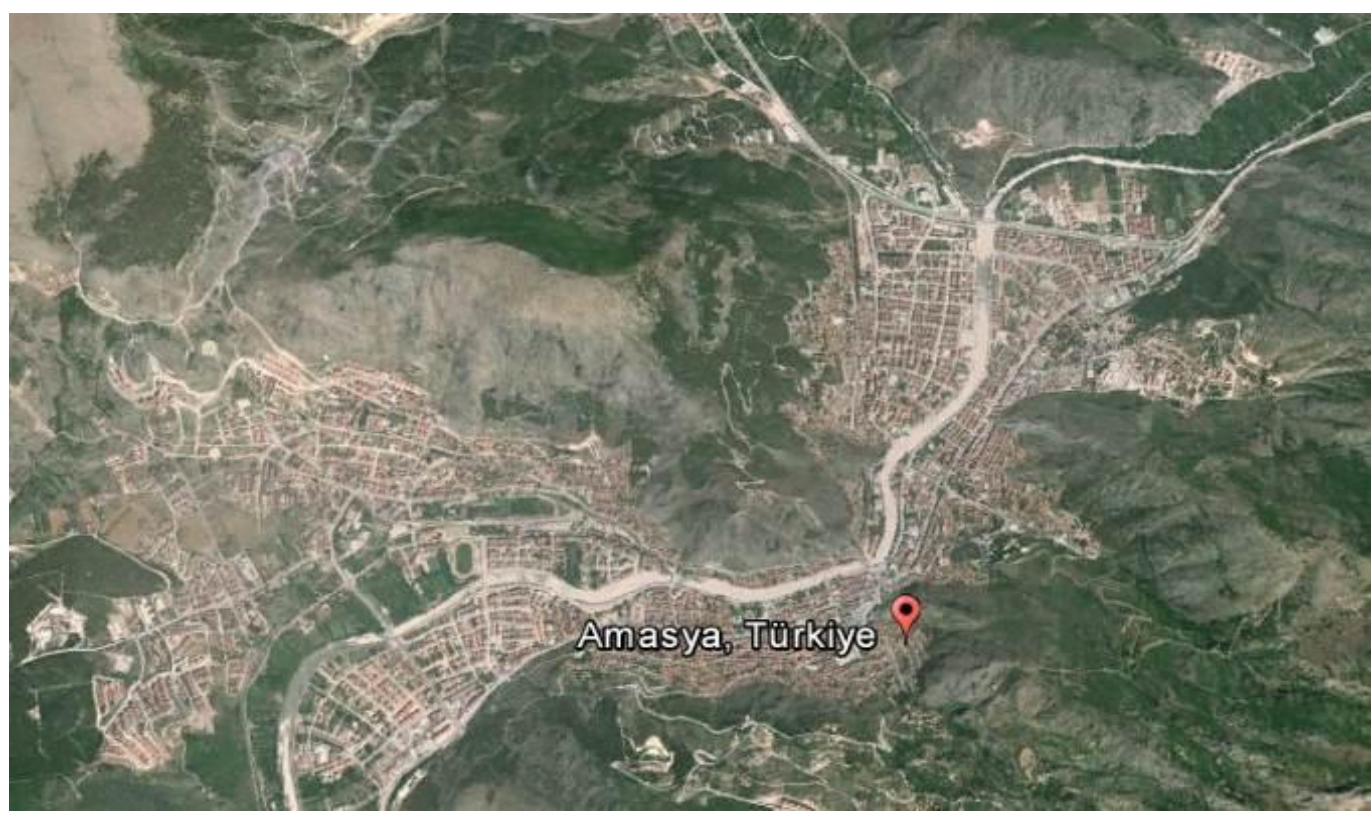

Şekil 1. Amasya kentinin makroformu (Kaynak: Google Earth'den alınmıştır)

(Figure 1. Urban macroform of Amasya City) (Source: Adopted from Google Earth)

Çorum ve Tokat'tan gelen D-180 karayolu, kent merkezine yaklaşık 12 kilometre kala birleşip, D-100 yolu olarak kentin içinden geçmekte, doğrusal olarak uzanan kentin diğer ucunda da; bir tarafı Samsun'a diğer tarafı da Erzincan-Erzurum'a olmak üzere ikiye ayrılmaktadır. Adı geçen kentler arasındaki tüm şehirlerarası trafik de, zorunlu olarak Amasya kentinin tam ortasından geçmektedir.

Kentin coğrafi yapısından dolayı alternatif bir yol da bulunmadığından, ağır vasıtaların da içinde bulunduğu tüm trafik yükü kent merkezinde art arda yer alan Mustafa Kemal Caddesi, Atatürk Caddesi ve Mehmet Varinli Caddelerinde yoğunlaşmaktadır. Kentte otopark sorunundan dolayı bu üç caddenin oluşturduğu aks boyunca yol kenarlarına park edilmekte olup, trafik bu caddeler boyunca tek şeride düşüp ağırlaşmaktadır. Bu olumsuz durum da, çevresel gürültüyü trafiğe bağlı olarak artıran en önemli etken olarak karşımıza çıkmaktadır.

Kent içinden geçen şehirlerarası D-100 yoluna alternatif olarak 2010 yılında başlatılan 12 kilometrelik Amasya Çevre Yolu inşaatı halen devam etmektedir ve 2015 sonu itibarı ile de bitirilmesi planlanmaktadır. Çevre yolu bitirildiğinde mevcut ana arterin yükünü hafifleteceği kesindir. Bu hafifleme ancak ağır vasıtalar ile ilgili olacaktır. Her geçen yıl trafiğe çıkan otomobil sayısı düşünüldüğünde, kent içinde alternatif güzergahlar bulunmadıkça; Mustafa Kemal Caddesi, Atatürk Caddesi ve Mehmet Varinli Caddelerinin üzerinde yer aldığı D-100 karayolu trafik yoğunluğunu ilerleyen yıllarda da koruyacak gibi gözükmektedir.

Kent merkezini ele aldığımızda, yukarıda belirttiğimiz ana caddeleri belli oranda rahatlatan ve paralellerinde yer alan Ziya Paşa Bulvarı ve Mehmet Paşa Caddesi de zorunlu kent içi trafik yoğunluğundan dolayı trafik gürültüsünün yoğun olarak saptandığı ana caddelerdir. Amasya kent merkezi ölçeğinde bu saydığımız 5 caddeden başka ana arter de bulunmamaktadır. Bununla beraber, kentin güney kesiminde özellikle 1980'li ylllarla beraber apartmanlaşan ve hızla gelişme gösteren İstasyon Mahallesinin ana arteri olan İstasyon 
Caddesi de bir alt merkez olarak kent trafiğinin yoğun yaşandığı başlıca caddelerden altıncısıdır.

Gürültü ile ilgili bu çalışmamız adı geçen 6 cadde üzerinde yoğunlaşmıştır. Amasya kent merkezinde seçilmiş 54 referans noktada saptanan gürültü düzeylerinin istatistiki analizleri yapılmıştır (Şekil 2).

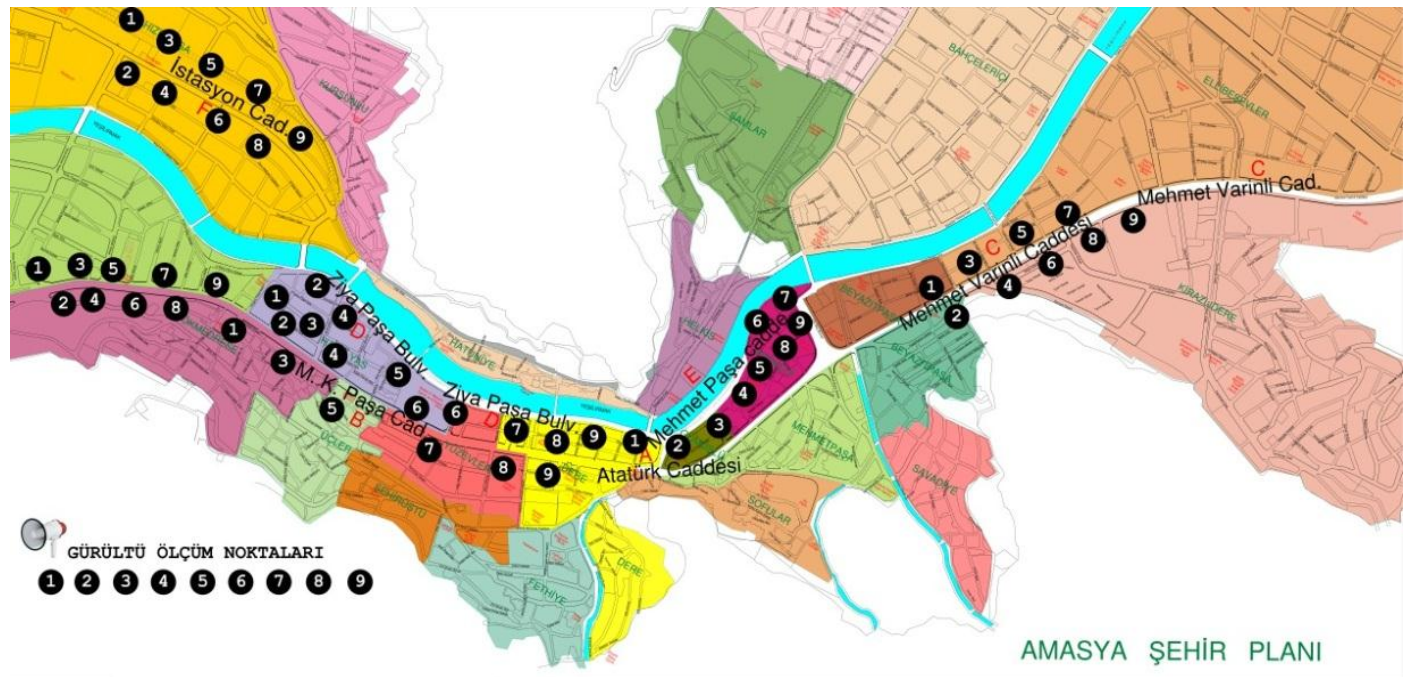

\begin{tabular}{|l|c|c|c|c|c|c|}
\hline Atatürk Caddesi & L10 & L50 & L90 & LNP & Leq & TNI \\
\hline Ortalama & 74.4 & 73.5 & 68.6 & 83.4 & 74.3 & 73.9 \\
\hline Mustafa Kemal Paşa Cad. & & & & & & \\
\hline Ortalama & 85.0 & 72.5 & 67.4 & 87.1 & 76.0 & 83.4 \\
\hline Mehmet Varinli Cad. & & & & & & \\
\hline Ortalama & 75.6 & 71.0 & 68.0 & 71.7 & 73.0 & 66.8 \\
\hline Ziya Paşa Bulvarı & & & & & & \\
\hline Ortalama & 77.0 & 73.0 & 69.6 & 83.5 & 75.2 & 71.3 \\
\hline Mehmet Paşa Cad. & 82.0 & 78.2 & 75.8 & 85.9 & 76.6 & 67.8 \\
\hline Ortalama & & & & & \\
\hline İstasyon Cad. & 70.8 & 66.5 & 63.6 & 76.0 & 69.7 & 62.4 \\
\hline Ortalama \\
Şekil 2. Amasya kent merkezinde ana caddelerde trafik gürültüsü ölçü
\end{tabular}
yapılan noktalar

(Figure 2. Traffic noise measurement points on avenues of Amasya City Center)

Ölçüm yapılan bölgelerde saptanan L10, L50, L90, Lmax ve Leq değerleri diğer araştırmalar sonucu bulunmuş gürültü düzeyleri ile de karşılaştırılmıştır. Amasya'da seçilmiş bölgeler içerisinden veya yakınından geçen trafik yollarına ait gürültü indislerinin kabul edilmiş olan L10, L50, ve L90 ölçüt değerleri ile karşılaştırması yapllarak, incelenen bölgelerde birimlere göre değişen kriterlerin veya sınır değerlerinin aşıldığı durumlar veya çelişkilerin ortaya konulması, bu araştırmanın amaçları arasında olup, bunun için istatistiksel gürültü düzeylerinin ağırlıklı olarak birleştirildiği TNI (Traffic Noise Index) değerleri araştırılmıştır (Tablo 1). 
Güremen, L.

NWSA-Engineering Sciences, 1A0353, 9, (4), 26-47.

Tablo 1. Amasya kent merkezindeki yollarda gürültü ölçüm sonuçları

(table 1. noise pollution measurement results on roads of Amasya City Center)

\begin{tabular}{|c|c|c|c|c|c|c|c|c|c|c|}
\hline \multirow[b]{2}{*}{ Bölge } & \multirow[b]{2}{*}{ Zaman } & \multirow[b]{2}{*}{ Gün } & \multicolumn{7}{|c|}{ İndis (dba) } & \multirow[b]{2}{*}{ Taşıt } \\
\hline & & & Akım & L10 & L50 & L90 & LNP & Leq & TNI & \\
\hline \multirow{10}{*}{$\begin{array}{l}\text { Atatürk } \\
\text { Caddesi }\end{array}$} & Sabah & \multirow{3}{*}{ Pazartesi } & DU. & 76.7 & 72.9 & 68.6 & 82.5 & 74.3 & 71.0 & 81 \\
\hline & Öğle & & $"$ & 78.3 & 72.0 & 68.3 & 85.3 & 75.2 & 78.2 & 77 \\
\hline & Akşam & & $"$ & 78.6 & 73.4 & 69.9 & 83.8 & 74.9 & 75.1 & 89 \\
\hline & Sabah & \multirow{3}{*}{ Çarşamba } & " & 74.5 & 71.1 & 66.9 & 81.9 & 73.2 & 74.4 & 86 \\
\hline & Öğle & & $"$ & 77.1 & 72.6 & 68.3 & 82.9 & 74.4 & 72.9 & 75 \\
\hline & Akşam & & $"$ & 74.2 & 68.9 & 65.2 & 80.0 & 71.0 & 72.0 & 82 \\
\hline & Sabah & \multirow{3}{*}{ Cuma } & " & 79.9 & 71.9 & 69.0 & 83.9 & 74.4 & 76.5 & 84 \\
\hline & Öğle & & " & 78.7 & 72.6 & 69.3 & 86.1 & 75.7 & 76.9 & 67 \\
\hline & Akşam & & " & 78.7 & 72.6 & 69.3 & 86.1 & 75.7 & 76.9 & 79 \\
\hline & \multicolumn{3}{|c|}{ Ortalama } & 77.4 & 73.5 & 68.6 & 83.4 & 74.3 & 73.9 & 83 \\
\hline \multirow{10}{*}{$\begin{array}{l}\text { Mustafa } \\
\text { Kemal } \\
\text { Caddesi }\end{array}$} & Sabah & \multirow{3}{*}{ Pazartesi } & DU & 81.0 & 75.2 & 70.4 & 88.1 & 77.6 & 82.8 & 85 \\
\hline & Öğle & & $"$ & 77.2 & 72.3 & 68.4 & 83.9 & 74.9 & 73.4 & 87 \\
\hline & Akşam & & $"$ & 79.3 & 73.2 & 68.3 & 84.9 & 76.6 & 81.0 & 91 \\
\hline & Sabah & \multirow{3}{*}{ Çarşamba } & $"$ & 79.0 & 72.5 & 64.0 & 90.2 & 75.6 & 93.8 & 72 \\
\hline & Öğle & & " & 77.5 & 71.4 & 65.0 & 85.2 & 74.0 & 85.0 & 83 \\
\hline & Akşam & & $"$ & 80.0 & 74.2 & 68.4 & 88.6 & 77.2 & 84.2 & 96 \\
\hline & Sabah & & " & 77.4 & 71.0 & 65.5 & 88.1 & 75.4 & 83.0 & 79 \\
\hline & Öğle & Cuma & $"$ & 81.0 & 73.8 & 67.7 & 90.4 & 78.1 & 90.1 & 88 \\
\hline & Akşam & & " & 77.4 & 72.9 & 69.1 & 84.6 & 75.2 & 78.0 & 96 \\
\hline & ortalc & & & 85 & 72.9 & 67.4 & 87.1 & 76.0 & 83.4 & 85 \\
\hline & Sabah & & DU. & 74.5 & 70. & 67.6 & 79.9 & 72.5 & 64.9 & 77 \\
\hline & Öğle & Pazartesi & $"$ & 75.2 & 70.9 & 68 & 80.6 & 73.0 & 64.3 & 86 \\
\hline & Akşam & & $"$ & 74.5 & 70.1 & 66.3 & 79.7 & 72.0 & 68.6 & 89 \\
\hline & Sabah & & $"$ & 78.4 & 75.1 & 72.4 & 82.4 & 76.3 & 66.6 & 96 \\
\hline Mehmet & Öğle & Çarşamba & $"$ & 74.6 & 70.8 & 67.6 & 80.4 & 72.9 & 65.3 & 92 \\
\hline varinel & Akşam & & $"$ & 75.6 & 71.6 & 68.7 & 80.4 & 73.2 & 67.1 & 87 \\
\hline & Sabah & & $"$ & 75.6 & 71.6 & 68.7 & 80.4 & 73.2 & 67.1 & 79 \\
\hline & Öğle & Cuma & $"$ & 74.5 & 69.7 & 66.8 & 79.7 & 72.0 & 68 & 96 \\
\hline & Akşam & & " & 75.6 & 69.5 & 67. & 82.8 & 73.2 & 71.1 & 89 \\
\hline & Ortalo & & & $"$ & 71. & 68.0 & 71.7 & 73.0 & 66.8 & 88 \\
\hline & Sabah & & DU. & 75.5 & 71.9 & 68.0 & 81.3 & 73.3 & 68.0 & \\
\hline & Öğle & Pazartesi & $"$ & 77.1 & 71.5 & 68.4 & 83.4 & 74.8 & 73.2 & 83 \\
\hline & Akşam & & $"$ & 77.3 & 73.1 & 68.1 & 84.0 & 74.6 & 74.9 & 75 \\
\hline & Sabah & & " & 77.7 & 73.5 & 70.2 & 83.8 & 75.6 & 70.2 & 78 \\
\hline Ziya & Öğle & Çarşamba & $"$ & 80.5 & 76.3 & 73.1 & 87.8 & 79.3 & 72.6 & 74 \\
\hline Paşa & Akşam & & $"$ & 76.6 & 73.3 & 70.7 & 80.8 & 74.6 & 64.1 & 81 \\
\hline Caddes I & Sabah & & " & 78.5 & 74.1 & 70.8 & 84.3 & 76.2 & 71.6 & 79 \\
\hline & Öğle & Cuma & $"$ & 77.5 & 71.6 & 67.6 & 83.2 & 74.5 & 77.1 & 69 \\
\hline & Akşam & & " & 77.0 & 72.1 & 69.1 & 83.0 & 74.7 & 70.7 & 71 \\
\hline & Ortala & & & $"$ & 73.0 & 69.6 & 83.5 & 75.2 & 71.3 & 76 \\
\hline & Sabah & & DU. & 81.6 & 77.9 & 75.9 & 84.8 & 78.6 & 67.8 & 87 \\
\hline & Öğle & Pazartesi & $"$ & 82.9 & 78.6 & 75.0 & 89.0 & 79.8 & 69.3 & 79 \\
\hline & Akşam & & $"$ & 81.6 & 78.2 & 75.7 & 85.6 & 79.7 & 69.4 & 88 \\
\hline & Sabah & & $"$ & 81.9 & 78.6 & 76.4 & 86.4 & 80.2 & 68.7 & 79 \\
\hline Mehmet & Öğle & Çarşamba & " & 80.7 & 77.6 & 75.5 & 84.1 & 78.8 & 66.4 & 91 \\
\hline $\begin{array}{l}\text { Paşa } \\
\text { Caddesi }\end{array}$ & Akşam & & $"$ & 81.5 & 79.6 & 77.1 & 84.3 & 80.1 & 64.7 & 93 \\
\hline & Sabah & & $"$ & 79.6 & 76.2 & 74.5 & 83.1 & 77.5 & 64.9 & 88 \\
\hline & Öğle & Cuma & " & 82.1 & 79.0 & 76.8 & 90.0 & 82.1 & 69.9 & 79 \\
\hline & Akşam & & " & 82.0 & 78.3 & 76.0 & 86.5 & 80.1 & 69.6 & 81 \\
\hline & Ortalc & & & $"$ & 78.2 & 75.8 & 85.9 & 79.6 & 67.8 & 85 \\
\hline & Sabah & & DU. & 66.3 & 63.7 & 61.0 & 70.1 & 64.7 & 52.2 & 74 \\
\hline & Öğle & Pazartesi & $"$ & 67.9 & 65.3 & 63.1 & 71.2 & 66.2 & 52.3 & 77 \\
\hline & Akşam & & " & 67.6 & 64.1 & 61.4 & 73.2 & 66.2 & 56.2 & 85 \\
\hline İstasyon & Sabah & & $"$ & 70.7 & 66.4 & 63.3 & 76.2 & 68.5 & 62.9 & 79 \\
\hline Caddesi & Öğle & Çarşamba & $"$ & 69.9 & 65.7 & 63.2 & 75.0 & 67.8 & 60 & 92 \\
\hline & Akşam & & $"$ & 69.8 & 65.7 & 63.0 & 77.3 & 68.8 & 60.6 & 87 \\
\hline & Sabah & & $"$ & 69.4 & 65.4 & 62.4 & 75.2 & 67.6 & 60.4 & 91 \\
\hline & Öğle & Cuma & " & 68.9 & 64.7 & 62.2 & 74.0 & 67.8 & 60 & 79 \\
\hline & Akşam & & " & 70.8 & 66.5 & 63.6 & 76.0 & 69.7 & 62.4 & 69 \\
\hline
\end{tabular}


Ölçüm noktalarının bulunduğu lokasyonlar birbirlerine göre trafik koşulları, gürültü düzeyleri, bina yükseklikleri, konumları gibi yönlerden benzerlikler göstermekte olup, binalar arası yansıma ve kırılmaların etkisi ile gürültü seviyelerinin değişiklik gösterdiği görülmektedir. Yapılan gürültü düzeyleri ölçüm ve değerlendirmeler sonucu belirlenmiş olan L10, L50, Leq, TNI ve LNP değerleri verilmiştir.

\subsection{Atatürk Caddesi (Atatürk Avenue)}

Kent merkezinde kentin önemli yol aksı ve şehirlerarası D-100 ve D-180 karayolu güzergahı üzerinde yer alan Atatürk caddesine Ziya Paşa Bulvarı, Mehmet Paşa caddesinden trafiğe olan katılımlarla oldukça karmaşık ve ağır bir trafik hacmine sahiptir. Atatürk caddesinde L10 birimindeki değişim pazartesi günü 1.6 dBA, Çarşamba 2.9 dBA ve Cuma günü 4.3 dBA kadardır. Tüm sabah saatleri ölçmeleri ise L10;max 2.2, öğle saatleri 1.6, akşam saatleri ölçmeleri ise 4.4 dBA'lık farklılıklar göstermektedir. L90'düzeyinin ise en fazla hafta ortası (Çarşamba)günü Max.3.1 dBA olduğu söylenebilir. L10'a göre daha fazladır. Bu sonuç ortamda yüksek arka plan gürültüsünün etkili olduğunu vurgulamaktadır. TNI değeri hafta başında $7.2 \mathrm{dBA}$ ölçülürken, hafta ortasında 2.4 dBA ve hafta sonunda $10.6 \mathrm{dBA}$ değişim göstermektedir. L10 düzeyindeki değişim ise sabah 5.9 dBA bir artış göstermektedir (Şekil 3).
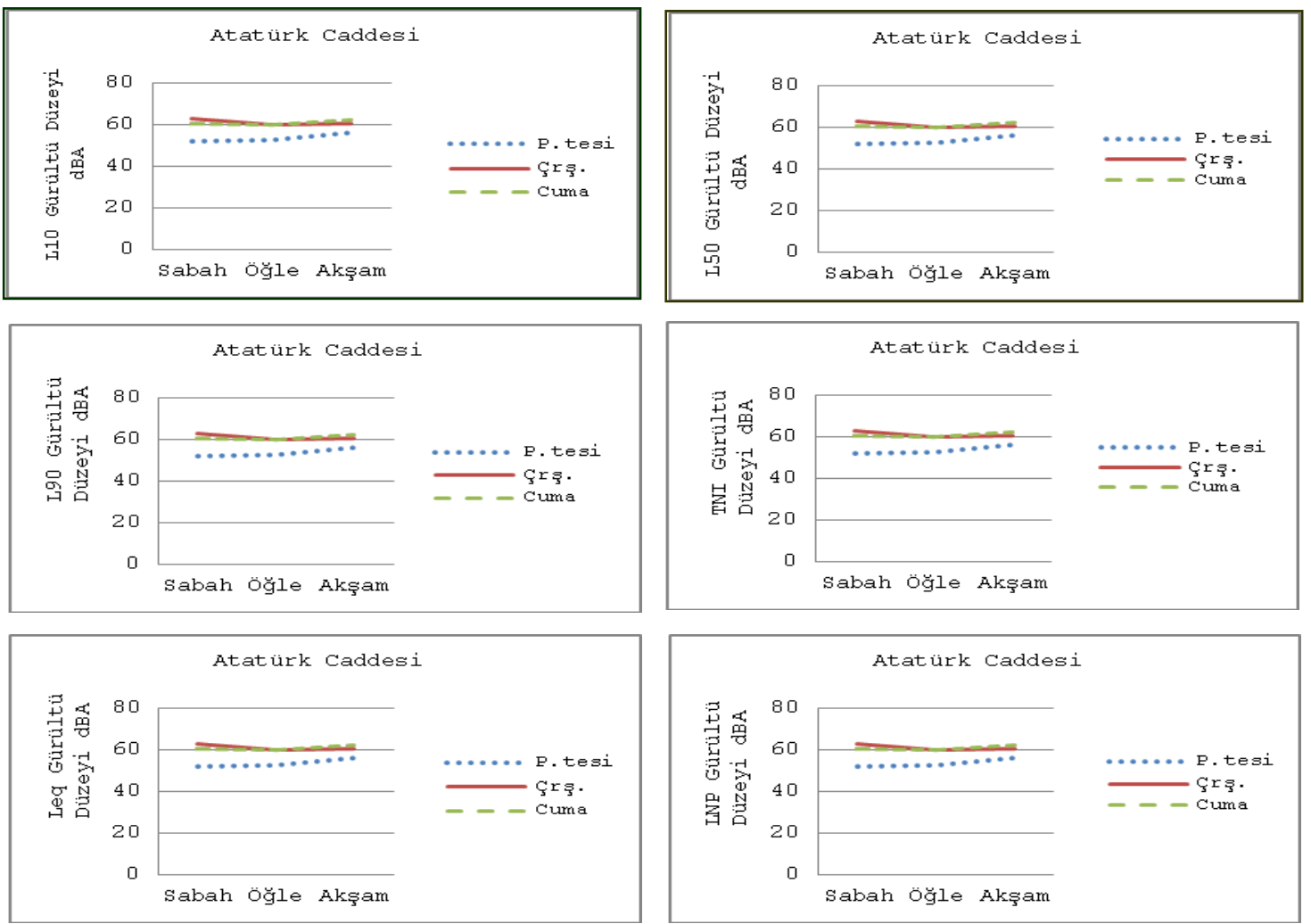

Şekil 3. Atatürk Caddesinde gürültü düzeylerinin günlük ve saatlik değişimi

(Figure 3. Daily and hourly change of noise levels in Atatürk Avenue)

Taşıt yoğunluğu gün içerisinde değişiklikler göstermektedir ve bu caddede saptanan maksimum trafik hacmi günlük ortalama 480 taşıt/saat olarak sayılmıştır. Cadde boyunca sağ şerit park eden 
araçlarca işgal edildiğinden trafik akımı tek şeride düşmekte ve trafik koşulları, duraklı olarak seyretmektedir. Yolun iki tarafında 5-6 katlı blok dizilerinin de neden olduğu yansıma ve kırılmalar gürültü düzeylerini olumsuz yönde etkilemektedir. Atatürk caddesinde taşıt verisi ile gürültü düzeyi arasında pozitif yönlü bir ilişki tespit edilmiştir.

\subsection{Mustafa Kemal Caddesi (Mustafa Kemal Avenue)}

Kent merkezinde kentin önemli yol aksı ve şehirlerarası D-100 ve D-180 kara yolu güzergahı üzerinde yer alan Atatürk caddesinin alt bölümünde yer almakta cadde kentin önemli alışveriş ve ticaret merkezi özelliğindedir. Ölçümler haftanın değişik 3 iş günü ve günün değişik saatlerinde yapılmıştır.

Gürültü dağılımı analizinde görüldüğü gibi belirlenen lokasyonlar da yapılan sürekli ses ölçümleri sonucunda saptanmış gürültü düzeyleri genel olarak, günlere ve saatlere göre değişim göstermektedir. Örneğin L10 düzeyinde, hafta başında $3.8 \mathrm{dBA}$, hafta ortasında $2.5 \mathrm{dBA}$, hafta sonunda 3.6 dBA kadar olup, pazartesi günü sabah, hafta sonu Cuma günü artış biçimindedir. Bununla birlikte değişik gürültü birimleri üzerinde bu değişimin etkisi de farklı olmaktadır. Örneğin TNI değeri hafta başında 9.4 dBA ve hafta sonunda 12.1 dBA'lık bir günlük değişim göstermektedir. Ölçülmüş tüm sabah, öğle ve akşam değerlerinin karşılaştırmasında, Pazartesi sabahları, diğer günlere göre; L10 düzeyinde 3.6 dBA bir artış gözlemlenirken, Cuma günü akşam ölçümlerinde 2.5 dBA azalma olduğu belirlenmiştir. Mustafa Kemal Caddesinde ölçülen gürültü düzeylerinin homojen olduğu saatler saat $11^{00}-17^{00}$ saatleri arasındadır.

Bu saatler iş dönüş saatlerini kapsamaktadır. Cuma günü taşıt sayısının maksimuma ulaştığı, trafik kompozisyonunun ise duraklı ve düşük taşıt hızlı bir akım şeklinde olduğu gözlemlenmiştir. Pazartesi, Çarşamba Cuma günlerinde sabah, öğle ve akşam saatlerinde taşıt sayısı ile yüksek sayılabilecek bir korelasyon bulunduğu tespit edilmiştir (Şekil 4).
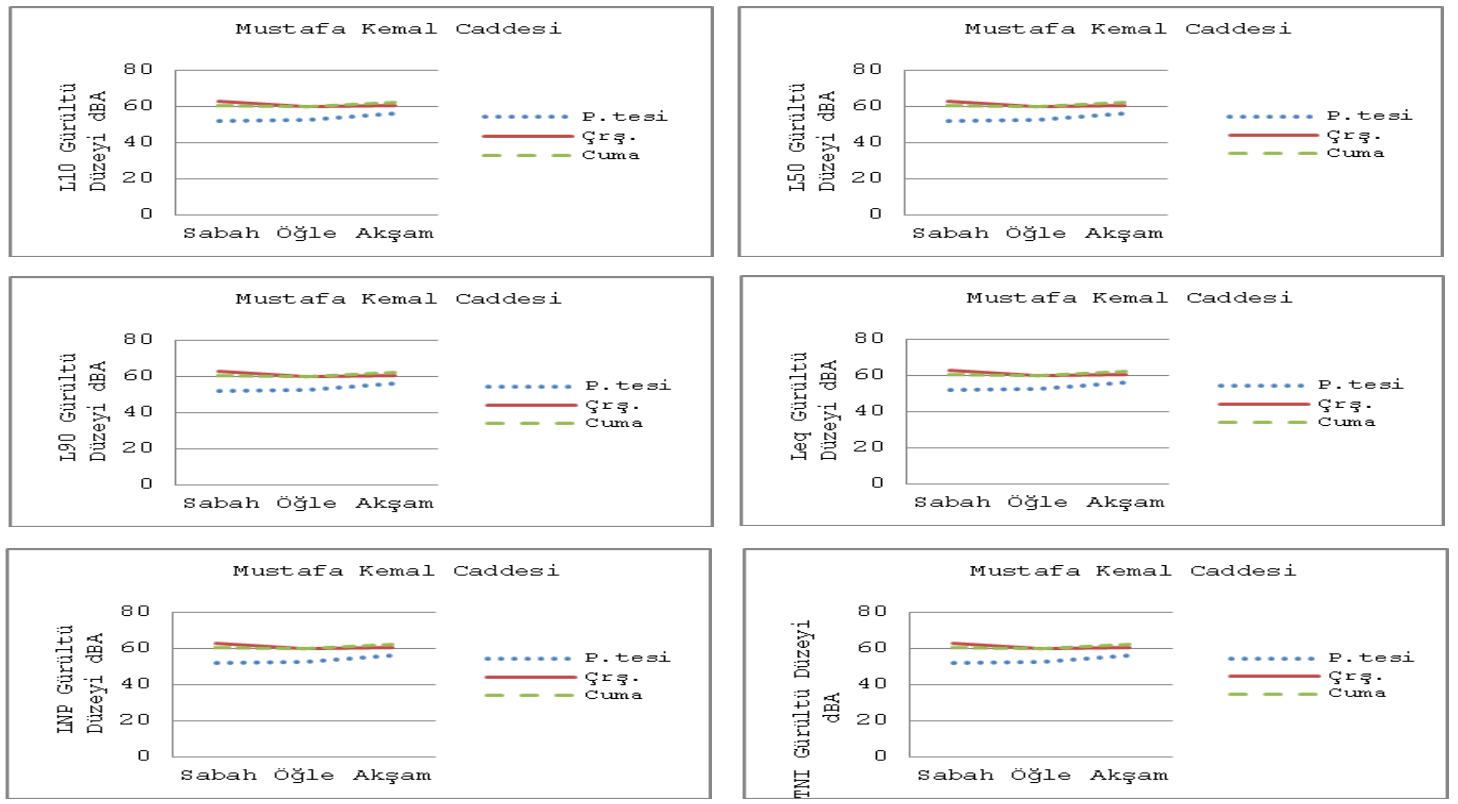

Şekil 4. Mustafa Kemal Caddesi gürültü düzeylerinin günlük ve saatlik değişimi

(Figure 4. Daily and hourly change of noise levels in Mustafa Kemal Avenue) 


\subsection{Mehmet Varinli Caddesi (Mehmet Varinli Avenue)}

Atatürk caddesinin devaminda yer almakta olan cadde yoğun bir trafik yükünü taşımaktadır. Sürekli ölçümlerin yapıldığı haftanın değişik iş günleri ve saatlerinde gürültü düzeylerinde değişimler gözlemlenmiştir. L10 düzeylerinde en fazla Çarşamba günü 3.9 dBA, L90'da ise yine Çarşamba günü 4.8 dBA günlük değişim belirlenmiştir. Ölçümleme yapılan hafta başı (pazartesi) günü L10 ve L90 düzeylerinde önemli bir değişim gözlemlenmemiştir (Şekil 5).
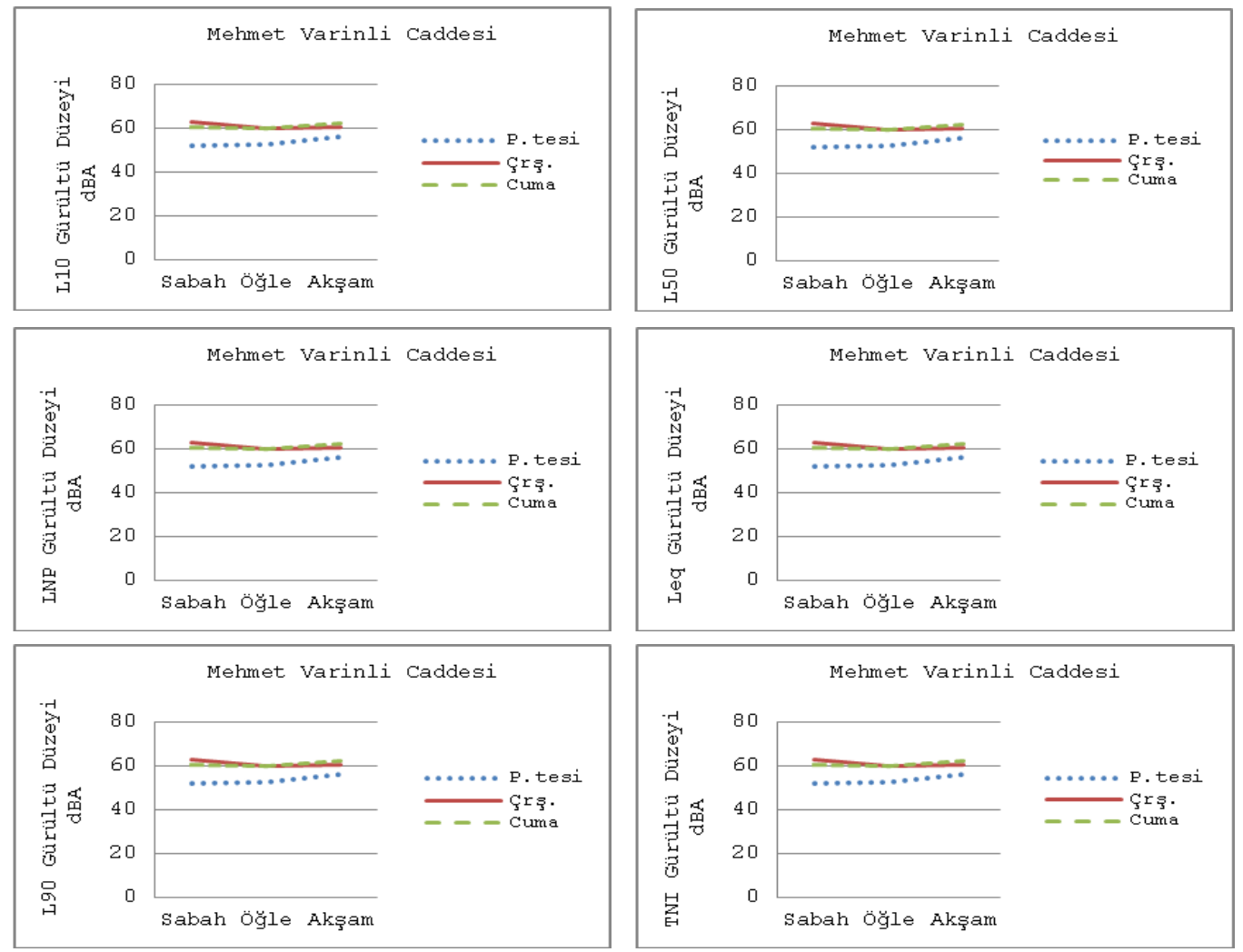

Şekil 5. Mehmet Varinli Caddesinde gürültü düzeylerinin günlük ve saatlik değişimi

(Figure 5. Daily and hourly change of noise levels in Mehmet Varinli Avenue)

L10 düzeylerinin saatlik analizleri, en çok öğle saatlerinde 3.2 dBA, L90 düzeylerinin saatlik analizi ise 5.6 dBA'lik bir farkı ortaya koymuştur. Sabah ve akşam saatleri düzeylerinde haftanın değişik günlerinde bir değişme olmadığı kabul edilebilir. Atatürk Caddesi Mustafa Kemal Paşa Caddesi, Mehmet Varinli Caddesi duraklı bir trafik kompozisyonuna sahiptir.

\subsection{Ziya Paşa Bulvarı (Ziyapaşa Boulevard)}

Ziya Paşa Bulvarı kentin entegrasyon değeri yüksek önemli yaya ve trafik arteri özelıiği taşımaktadır. Ziya Paşa Bulvarı ve Yeşilırmak(gezi yolu) promenantı, Kent merkezindeki trafik kompozisyonunu belli bir oranda rahatlatan alternatif olma özelliği ile Atatürk caddesi-Mustafa Kemal Caddesi ve Mehmet Varinli caddelerinin paralelinde yer almaktadır. Yeşilırmak tarafındaki Yalı boyu sahil promenatı(Gezi yolu), günün her saatinde, kentte yaşayanlarca dengeli bir biçimde kullanılmaktadır. Bu durum, yalı boyu 
sahil promenatının kent içi konumu ve başlangıçtan itibaren rekreasyon amaçlı planlanmasının sonuçları ile ilişkilendirilebilir. Mustafa Kemal Paşa Caddesi ve Ziya Paşa Bulvarı'nda gerçekleşen gelişmelere bağlı olarak, belirli bir değişim sürecinden geçtiği ifade edilebilmektedir. Ziya Paşa Bulvarında, belirlenmiş olan bölgelerde yapılmış olan ölçümlerin sonuçlarına dayanılarak, günlük L10 gürültü değişiminin, maksimum 3.9 dBA ile Çarşamba günü, minimum 1.5 dBA ile Cuma günü olduğu belirtilebilir. Ziya Paşa Bulvarı ve Mehmet Paşa Caddesi trafik kompozisyonu, trafik gürültüsünün yoğun olarak hissedildiği caddelerdir. L10 düzeyi olarak tüm sabah ölçmeleri arasındaki fark 3.0 dBA, öğle ölçmeleri 3.4 dBA, akşam ölçmeleri ise 0.7 dBA olarak belirlenmiştir. L90 düzeyinin ise maksimum 3.2 dBA, minimum 0.4 dBA sapma göstermesi haftanın ilk günü olan pazartesi günü olduğu belirlenmiştir(Şekil 6).
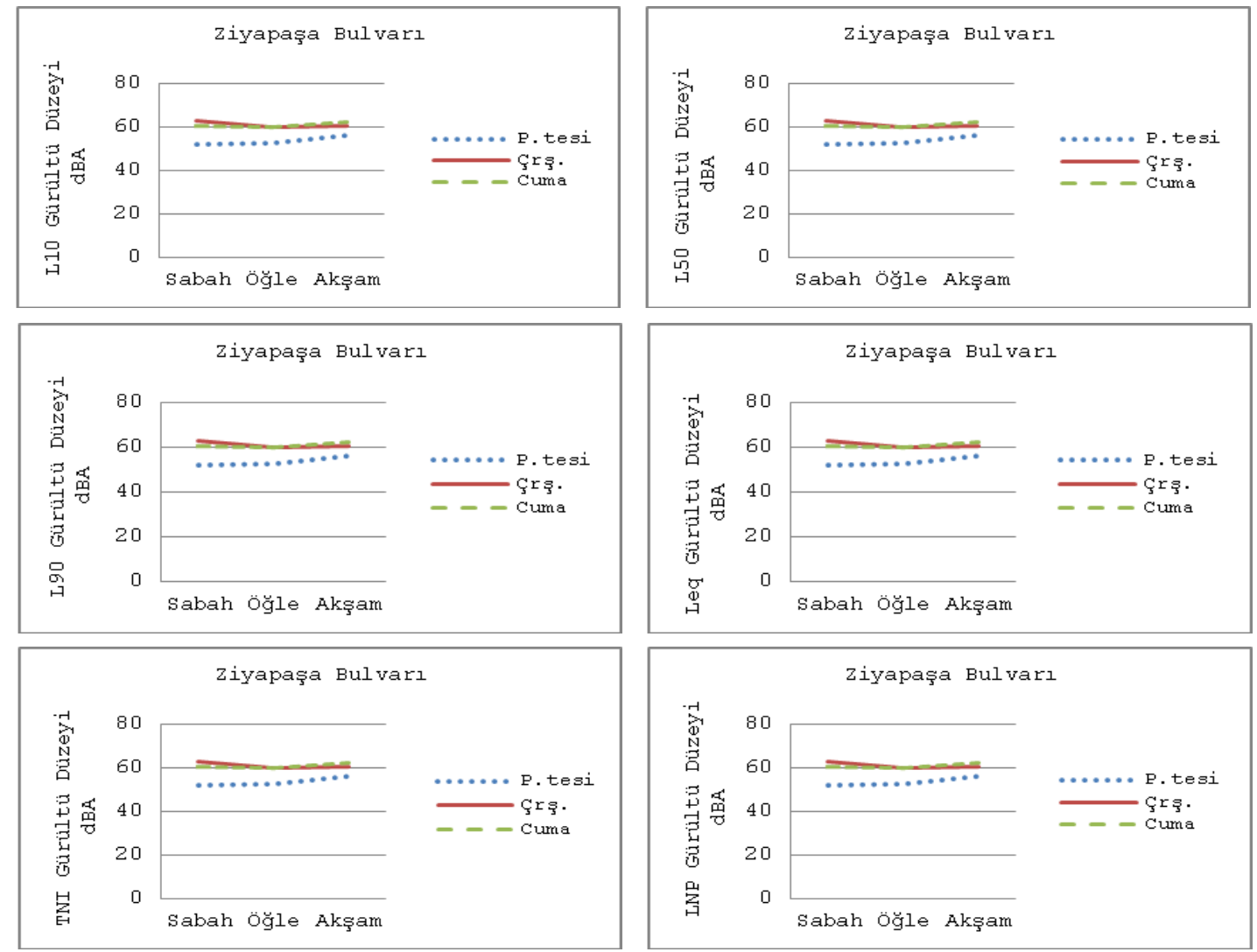

Şekil 6. Ziya Paşa Bulvarında gürültü düzeylerinin günlük ve saatlik değişimi

(Figure 6. Daily and hourly change of noise levels in ziyapaşa Boulevard)

L90 düzeylerin de en fazla değişimin öğle saatleri ölçmelerinde görüldüğü ve 5.5 dBA olduğu belirlenmiştir. Sürekli ölçüm yapılan Ziya Paşa bulvarında yol genişliği ve iki yönlü bir şeridin araçlarca park nedeniyle işgal edilmesi nedeniyle tıkanmalar görüldüğünden gürültü düzeyleri ve taşıt yoğunlukları arasındaki negatif ilişki gözlemlenmiştir.

\subsection{Mehmet Paşa Caddesi (Mehmet Paşa Avenue)}

Kent merkezini ele aldığımızda, Ziya Paşa Bulvarı ve Yeşilırmak (gezi yolu) promenantı, Mehmet Paşa caddesi, alışveriş merkezi olma özellikleri yanı sıra Kent merkezindeki trafik kompozisyonunu belli 
bir oranda rahatlatan alternetif olma özelliği taşımaktadır. Yalı boyunca Sahil promenatı(Gezi yolu), günün her saatinde, kentte yaşayanlarca dengeli bir biçimde kullanmaktadırlar. Bu durum, yalı boyu sahil promenatı'nın kent içi konumu değerlendirildiğinde başlangıçtan itibaren rekreasyon amaçlı planlanmasının sonuçları ile ilişkili görülmektedir. Yolun trafik yükü ve koşulları ve gürültü düzeylerinin günlük değişmeleri ölçümlerle değerlendirilmiştir.

L10 da, Çarşamba $1.2 \mathrm{dBA}$ ve hafta sonu (Cuma)günleri $2.5 \mathrm{dBA}$ olarak tespit edilmiştir. Tüm sabah saatleri ölçmeleri ise, L10 max. 2.5 dBA, öğle saatleri: max. 2.2 dBA ve akşam saatleri $0.5 \mathrm{dBA}$ lık bir değişim göstermektedir. Ancak L90 düzeyleri her iki yönden incelendiğinde farklılıklar L10'a göre daha azdır. Bu sonuç, yüksek arka plan gürültüsünün varlığını ve saatlere göre belirgin bir düzeyde değişmediğini vurgulamaktadır (Şekil 7).
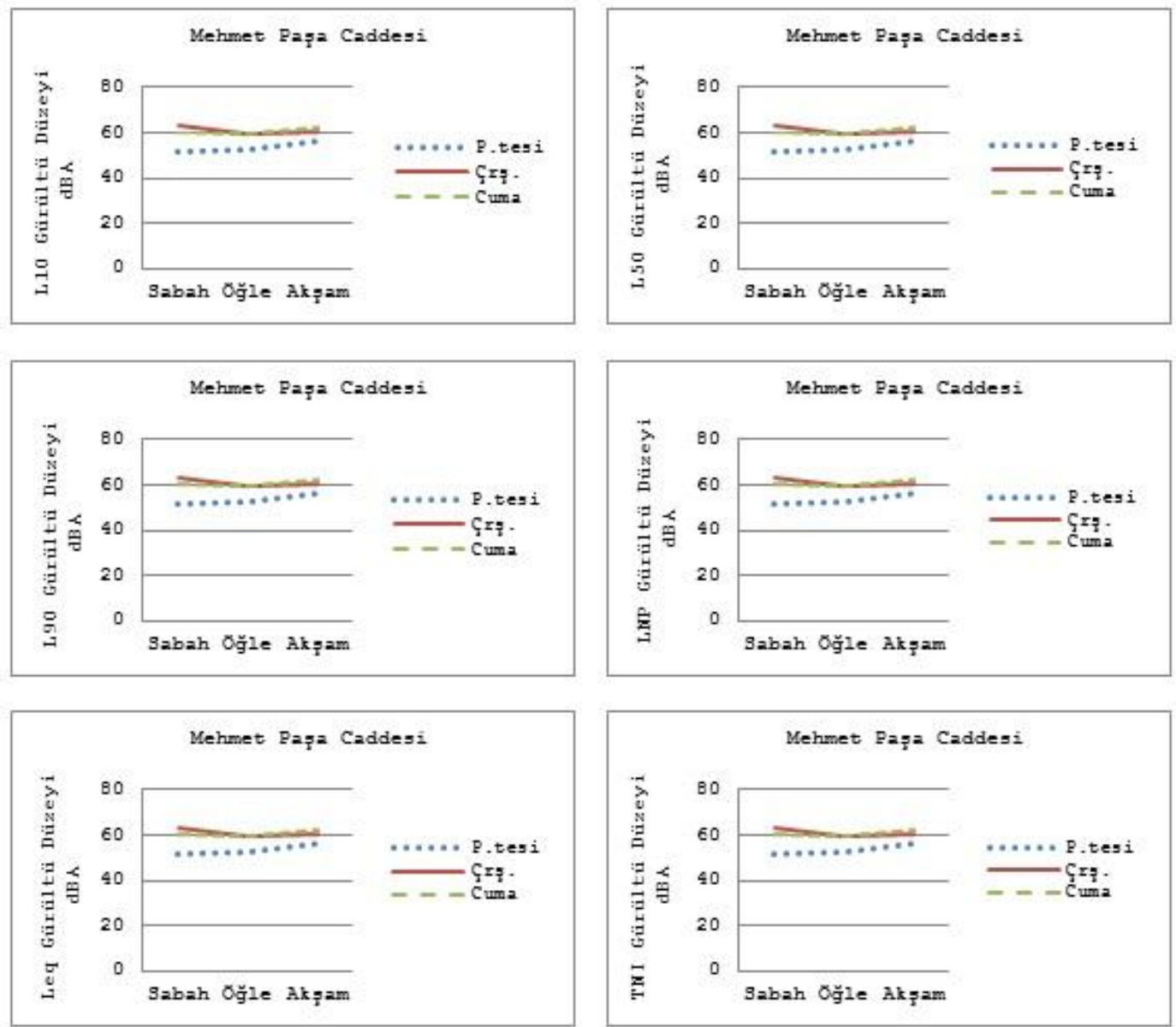

Şekil 7. Mehmet Paşa Caddesi gürültü düzeylerinin günlük ve saatlik değişimi

(Figure 7. Daily and hourly change of noise levels in Mehmet Paşa Avenue)

Ziya Paşa Bulvarı ve Mehmet Paşa Caddesi trafik kompozisyonu, trafik gürültüsünün yoğun olarak hissedildiği caddeler olup, elde edilen bulgular bu yargıyı desteklemektedir.

\section{6. İstasyon Caddesi (Istasyon Avenue)}

İstasyon Caddesi kentin güney kesiminde, özellikle 1980'li ylllarla beraber apartmanlaşan ve hizla gelişme gösteren bir alt merkez ve ana trafik arteri olma özelliğindedir. Bir alt merkez olarak 
kent trafiğinin yoğun olarak yaşandığı bir caddedir. Bu bölgede gürültü ölçümleri, etkilenmenin gerçek düzeylerini bulmak amacıyla, yola cephesi olan konut bloklarının yakınında yapılmış, ancak bir akşamüstü saatinde ana yol kenarında da tekrarlanmıştır.

Yol kenarındaki ölçülen düzeyler kentin diğer caddelerinde ölçülen düzeylere göre farklılık göstermektedir. Düzeylerde günlere göre olan dalgalanmalara bu bölgede en az olduğu görülmüştür. Gürültü düzeylerinin taşıt yoğunluğuna göre değişimi için, sabah ve akşam saatlerinde yoğun trafiğin duraklılık göstermesi nedeniyle kesin bir yargıya varılamamıştır. Konutları etkileyen düzeyler ise, aynı saatlerde $70.8 \mathrm{dBA}$ bulunmuştur. Saatlere göre örneğin L10 biriminde 4.5 dBA düzey farkı vardır. L90 da ise değişimler daha azdır(Şekil 8).
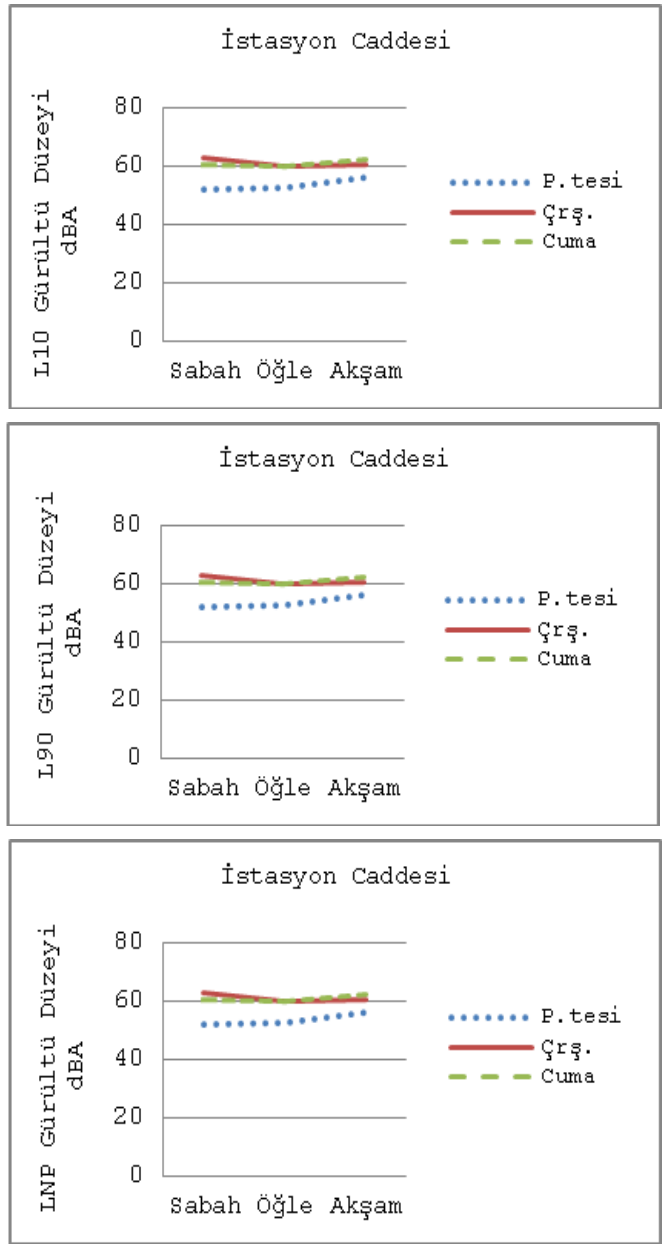
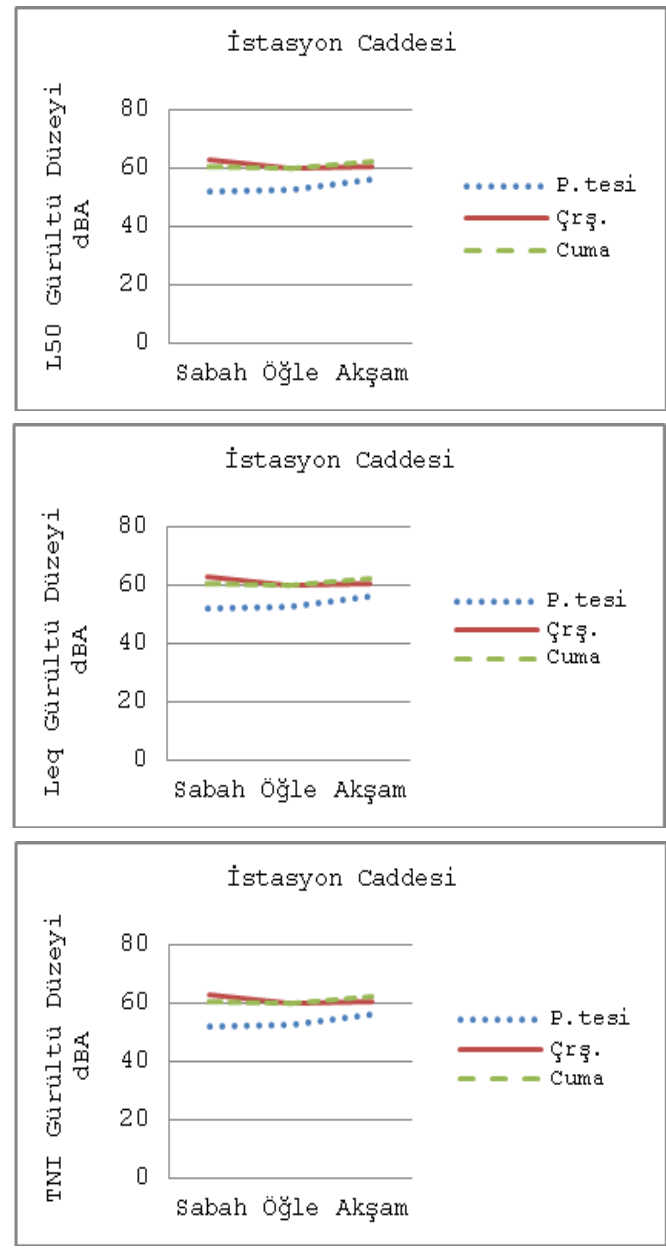

Şekil 8. İstasyon Caddesinde gürültü düzeylerinin günlük ve saatlik değişimi

(Figure 8. Daily and hourly change of noise levels in Istasyon Avenue)

İstasyon Caddesinde, nispeten yoğun trafiğin, değişmeyen bir arka plan gürültüsü yarattığı söylenebilir.

\section{SONUÇ (CONCLUSION)}

Yukarıda, kentin farklı ulaşım arterlerine göre yapılmış analizler ayrı ayrı açıklanmıştır. Bu arterler; trafik koşulları, gürültü düzeyleri gibi çeşitli yönlerden incelendiğinde birbirlerine göre benzerlikler göstermekle birlikte, tüm bu ulaşım sistemi Amasya 


\begin{tabular}{llll}
\hline \hline kentini temsil ettiğinden, sonuçların bir arada değerlendirmesi \\
gerekmektedir.
\end{tabular}
ulaşılmıştır.

Her bir bölge için saptanmış ve gürültünün istatistiksel analizlerinden elde edilmiş L10, L50, L90 (zamanin \%10unda, 50 sinde, o90unda aşılmış olan düzeyler)ölçümlerle belirlenmiştir. Çalışma yapılan tüm bölgelerdeki trafik hacmi ile gürültü düzeyleri arasındaki ilişkiler aranmış ve ayrı ayrı bölgeler için sonuçlar ölçümleme yapılan günler (pazartesi, Çarşamba, Cuma) ve günün farklı saatlerine (sabah, öğle, akşam) göre değerlendirildiğinde, taşıt yoğunluğu ile gürültü düzeyleri arasında kuvvetli bir korelasyonun olduğu yargısına varılmıştır (Tablo 2).

Tablo 2. Farklı günler ve zamanlarda ölçülen trafik gürültü düzeyleri ve taşıt sayıları arasındaki korelasyon

(Table 2. Correlation between traffic noise levels at times of day and number vehicles)

\begin{tabular}{|l|l|l|l|l|l|l|}
\hline $\begin{array}{l}\text { Günler/Gürültü } \\
\text { Indisleri }\end{array}$ & L10 & L50 & L90 & LNP & Leq & TNI \\
\hline Pazartesi & 0,9534 & 0,9352 & 0,9136 & 0,9279 & 0,9502 & 0,7423 \\
\hline Çarşamba & 0,9696 & 0,9289 & 0,7648 & 0,8712 & 0,9517 & 0,4302 \\
\hline Cuma & 0,9605 & 0,9793 & 0,9148 & 0,9218 & 0,9933 & 0,5066 \\
\hline $\begin{array}{l}\text { Günün } \\
\begin{array}{l}\text { Zamanları/Gürültü } \\
\text { Indisleri }\end{array}\end{array}$ L10 & L50 & L90 & LNP & Leq & TNI \\
\hline Sabah & 0,9562 & 0,9393 & 0,8305 & 0,8519 & 0,9633 & 0,5609 \\
\hline Öğle & 0,9587 & 0,6106 & 0,3976 & 0,7993 & 0,6811 & 0,8132 \\
\hline Akşam & 0,9323 & 0,8696 & 0,7955 & 0,9328 & 0,8778 & 0,7057 \\
\hline
\end{tabular}

Gürültü düzeyine bakıldığı zaman gerek ölçüm yapılan tüm günlerde, gerekse günlerin farklı zamanlarında (sabah-öğle-akşam) gürültü düzeyleri ve taşıt sayısı arasında yüksek bir korelasyon bulunmaktadır. Türkiye İstatistik Kurumu (TÜIK), 2014 verilerine göre Amasya'nın nüfusu 90.665 kişidir. (www.tuik.gov.tr) Aynı kaynak verilerine göre ilde, motorlu kara taşıtı sayısı 48.973 dür. Mevcut taşıtların yüzde 51'ini otomobil, yüzde 16,5'ini kamyonet, yüzde 15,5'ini motosiklet, yüzde 8,8'ini traktör, yüzde 4,4'ünü kamyon, yüzde 2,3'ünü minibüs, yüzde 1,4'ünü otobüs, yüzde 0,2'sini ise özel amaçlı taşıtlar oluşturmaktadır [17].

Ölçülen düzeyleri sadece gün olarak ele aldığımızda ölçülen düzeyler ile taşıt sayısı arasındaki yüksek korelasyonun L50, L90, indisleri içinde geçerli olmasında; arka plan gürültüsünün etken olduğu düşünülmektedir. Korelasyon katsayıları incelendiğinde dikkat çeken bir nokta olarak L90 düzeyinde öğle ölçümlerinde ölçülen gürültü düzeyleri ile geçen taşıt sayısı arasında oldukça düşük $(0,39)$ bir korelasyon saptanmıştır. Bu durumda taşıt yoğunluğunun düzeylere etkisi olmadığı saptanmıştır. Bunda durakıı akımların oluşturduğu negatif ilişkinin varlığının etken neden olduğu açıktır.

Amasya özelinde yapılan bu çalışmadan elde edilen bulgular yardımıyla, diğer araştırmaların sonuçları ile gürültü kirliliği açısından karşılaştırma ve değerlendirmeler yapılabilmiştir. İncelenen bölgelerde geçerli gürültü koşullarının kantitatif değerlerinin ortaya konulduğu araştırmada saptanan gürültü düzeylerinin günlük ortalama trafik hacmi ile yüksek korelasyon içinde olduğu bulunmuştur. Bu bulgu ve sonuçlar yardımıyla, trafik hacminin gürültüden rahatsızlığı nasıl etkilediği, konutlarda rastlanabilen genel fiziksel ve sosyal çevre sorunlarını ortaya koymak ve bina içi gürültü sorunun ayrıca yeni bir araştırmanın konusu olabilecek özelliktedir. 
Amasya'da belirlenmiş bölgelerde saptanan gürültü indislerinin değerleri, diğer ülkelerde yapılan benzer araştırmalar sonucu ölçülmüş Lmax ölçümleri 63.0 dBA, gürültü düzeyleri ile karşılaştırıldığında Mill Valley City için 63.0 dBA, Italya'da Messina City için 72.9 dBA Kwara State Nigeria Kwara State için 80.0 dBA, Kanada Regina Saskatchewan için 73.8 dBA, İtalya Mesina 72.9 dBA olan düzeyler Amasya Atatürk caddesi için 79.9 dBA, Mustafa Kemal Paşa Caddesi için 81.0 dBA, Mehmet Varinli Caddesi için 78.4 dBA, Ziya Paşa Bulvarı için 80.5 dBA, Mehmet Paşa Caddesi için 82.9 dBA, İstasyon Caddesi için 70.9 dBA olarak belirlenmiştir. Ölçüm çalışması yapılan bölgelerin tümü Amasya kentini temsil ettiğinden, Amasya için trafik gürültüsü koşullarının çok ciddi boyutlarda olduğunu ortaya koymaktadır (Tablo 3).

Tablo 3. Trafik gürültüsü bölgelerine ilişkin ölçme sonuçlarının karşılaştırması

(Table 3. Comparison of measuring results for traffic noise regions)

\begin{tabular}{|c|c|c|c|c|c|}
\hline & İndis & $\operatorname{MAX}(\mathrm{dBA})$ & ORT (dBA) & MİN (dBA) & Taşıt/h \\
\hline \multirow{3}{*}{ Atatürk cd. } & L10 & 79.9 & 77.0 & 74.2 & \multirow{3}{*}{480} \\
\hline & L50 & 73.4 & 71.8 & 68.9 & \\
\hline & L90 & 69.9 & 68.2 & 65.2 & \\
\hline \multirow{3}{*}{$\begin{array}{l}\text { Mustafa } \\
\text { Kemal Paşa } \\
\text { Caddesi }\end{array}$} & L10 & 81.0 & 78.8 & 77.2 & \multirow{3}{*}{511} \\
\hline & L50 & 75.2 & 72.9 & 71.0 & \\
\hline & L90 & 70.4 & 67.4 & 64.0 & \\
\hline \multirow{3}{*}{$\begin{array}{l}\text { Mehmet } \\
\text { Varinli } \\
\text { Caddesi }\end{array}$} & L10 & 78.4 & 75.3 & 74.5 & \multirow{3}{*}{504} \\
\hline & L50 & 75.1 & 70.9 & 69.5 & \\
\hline & L90 & 72.4 & 75.5 & 66.3 & \\
\hline \multirow{3}{*}{$\begin{array}{l}\text { Ziya Paşa } \\
\text { Bulvarı }\end{array}$} & L10 & 80.5 & 77.5 & 75.5 & \multirow{3}{*}{760} \\
\hline & L50 & 76.3 & 73.0 & 71.5 & \\
\hline & L90 & 70.7 & 69.6 & 67.6 & \\
\hline \multirow{3}{*}{$\begin{array}{l}\text { Mehmet } \\
\text { Paşa } \\
\text { Caddesi }\end{array}$} & L10 & 82.9 & 81.5 & 79.6 & \multirow{3}{*}{510} \\
\hline & L50 & 79.0 & 78.2 & 76.2 & \\
\hline & L90 & 77.1 & 75.8 & 74.5 & \\
\hline \multirow{3}{*}{$\begin{array}{l}\text { İstasyon } \\
\text { Caddesi }\end{array}$} & L10 & 70.8 & 69.0 & 66.4 & \multirow{3}{*}{475} \\
\hline & L50 & 66.5 & 50.9 & 63.7 & \\
\hline & L90 & 64.1 & 62.8 & 61.4 & \\
\hline \multirow{3}{*}{$\begin{array}{l}\text { Terminal } \\
\text { Caddesi }\end{array}$} & L10 & 73.0 & 72.7 & 72.5 & \multirow{3}{*}{630} \\
\hline & L50 & 81.0 & 68.5 & 67.8 & \\
\hline & L90 & 70.4 & 65.0 & 54.6 & \\
\hline \multirow{3}{*}{$\begin{array}{l}\text { Türkistan } \\
\text { Caddesi }\end{array}$} & L10 & 81.0 & 79.1 & 77.2 & \multirow{3}{*}{504} \\
\hline & L50 & 75.2 & 73.5 & 75.2 & \\
\hline & L90 & 70.4 & 69.0 & 68.3 & \\
\hline \multirow{3}{*}{$\begin{array}{l}\text { Kwara State, } \\
\text { Nigeria }\end{array}$} & L10 & 80.0 & 76.3 & 73.4 & \multirow{3}{*}{ - } \\
\hline & L50 & 72.8 & 69.1 & 63.0 & \\
\hline & L90 & 66.1 & 62.0 & 54.3 & \\
\hline Regina, & L10 & 73.8 & 72.0 & 69.4 & \multirow{3}{*}{-} \\
\hline Saskatchewan & L50 & 68.0 & 65.5 & 62.1 & \\
\hline Kanada & L90 & 59.7 & 61.3 & 54.4 & \\
\hline \multirow{3}{*}{ Mill Valley City } & L10 & 63.0 & 57.0 & 59.0 & \multirow{3}{*}{-} \\
\hline & L50 & 60.0 & 52.8 & 52.0 & \\
\hline & L90 & 55.0 & 49.3 & 49.0 & \\
\hline \multirow{3}{*}{ Messina Italy } & L10 & 72.9 & 68.0 & 64.0 & \multirow{6}{*}{-} \\
\hline & L50 & 72.0 & 67.0 & 58.0 & \\
\hline & L90 & 71.9 & 61.0 & 52.0 & \\
\hline \multirow{3}{*}{ Nigeria Capital } & L10 & 62.2 & 68.9 & 64.7 & \\
\hline & L50 & 68.2 & 67.6 & 58.5 & \\
\hline & L90 & 71.9 & 61.0 & 52.0 & \\
\hline
\end{tabular}


Bu çalışmadan elde edilen bulgular trafik gürültüsü konusunda başka araştırmacılar tarafından yapılan çalışmaların sonuçları ile karşılaştırıldığında; Oyedepo Sunday Olayinka'ın Nigeria Kwara State (2012) için ölçmüş olduğu düzeylerle paralellik arz ettiği görülmektedir[18].

Atatürk Caddesi için ölçülen ortalama düzeyler karşılaştırıldığında L10; 12.5 dBA, L90; 10.1 dBA, Leq; 3.6 dBA yüksek, Mustafa Kemal Caddesi için L10 17.2 dBA, L90 8.9 dBA, Leq 5.3 dBA yüksek Mehmet Varinli caddesinde ölçülen L10 16.4 dBA daha düşük, L90 4.0 dBA düşük, Leq 10.6 dBA düşük, Mehmet Paşa Caddesi için L10 10.0 dBA düşük,L90 11.0 dBA düşük, Leq 15.0 dBA düşük, İstasyon Caddesinde L10 21.2 dBA düşük, L90 8.4 dBA düşük, Leq 16.3 dBA düşük düzeyler ölçülmüştür.

L.Doi ve diğerlerinin Kanada'nın Regina Şehrinde (2012) trafik gürültüsünün yoğun olduğu yerleşim bölgelerinde yaptıkları çalışmada ölçtükleri düzeyler [19]; bu çalışmada ölçülen düzeyler ile karşılaştırıldığında, Atatürk caddesinde L10 15.2 dBA yüksek, L90 10.1 dBA yüksek, Leq 3.6 dBA yüksek düzeyler ölçülmüştür. Mustafa Kemal Caddesi için L10 22.6 dBA yüksek, L90 8.9 dBA yüksek, Leq $5.3 \mathrm{dBA}$ yüksek. Mehmet Varinli Caddesi için L10 13.4 dBA yüksek, Ziya Paşa Bulvarı için L10 14.8 dBA daha yüksek, L90 11.1 dBA yüksek, Leq 4.5 dBA yüksek, Mehmet Paşa Caddesi L10 19.8 dBA yüksek, L90 27.3 dBA yüksek, Leq 8.9 dBA yüksek, İstasyon Caddesi L10 8.6 dBA yüksek, L90 5.1 dBA yüksek, Leq 1.0 dBA düşük düzeyler ölçülmüştür.

Srimanta Gupta, Chitralekha Ghatak (2011); tarafından Hindistan'ın batı Burudwan kentinde yoğun trafik yolları üzerinde 5 yerleşim bölgesinde yapmış oldukları çalışmada ortalama L10 77.1 dBA, L50 76.9 dBA L90 76.3 dBA, Leq 78.1 dBA ölçmüşlerdir (20). Bu değerler Atatürk caddesinde ölçülen L10 0.3 dBA yüksek, L50 6.2 dBA düşük, L90 10.9 dBA düşük, Leq 13.8 dBA düşük ölçülmüştür. Bu değerler Mustafa Kemal Caddesi için sırasıyla L10 8.6 dBA yüksek, L50 6.0 dBA düşük, L90 8.9 dBA düşük, Leq 1.5 dBA düşük düzeylerdir. Mehmet Varinli Caddesinde ölçülen L10 1.5 dBA düşük, L50 6.1 dBA düşük, L90 8.3 dBA düşük, Leq dBA düşük düzeylerdir.

Kentin başlıca ve 2. alternatif caddesi olan Ziya Paşa Caddesinde ölçülen L10 0.1 dBA düşük, L50 3.9 dBA düşük, L90 6.7 dBA düşük, Leq 7.1 dBA yüksek ölçülmüştür. Mehmet Paşa Caddesi için ölçülen L10 3.9 dBA yüksek, L50 1.3 dBA yüksek, L90 6.7 dBA yüksek, Leq 13.4 dBA düşük ölçülmüştür. Kentin alt yerleşim bölgesinin önemli caddesi olan İstasyon caddesinde ölçülen düzeyler L10 6.3 dBA düşük, L50 10.4 dBA düşük, L90 12.7 dBA düşük, Leq 8.3 dBA daha düşük düzeylerdir.

I., Tosun ve arkadaşları (2012) Isparta ili için trafiğin yoğun olduğu 26 noktada yaptıkları gürültü ölçümlerinde Leq değerini 63.764.0 dBA ölçmüşlerdir. Ölçülen gürültü düzeylerinin yönetmeliklerde belirtilen sınırları aşmış olduğunu belirlemişlerdir [21] .

Bu düzeyler; Atatürk Caddesinde ölçülen Leq düzeylerinin ise Leq(63.7) için 10.6 dBA yüksek, Mustafa Kemal Caddesi için Leq(63.7) 12.3 dBA yüksek, Mehmet Varinli Caddesi için Leq(63.7) 9.3 dBA yüksek, Ziya Paşa Caddesi için Leq(63.7) 11.5 dBA yüksek, Mehmet Paşa caddesi için Leq(63.7) 18.9 dBA yüksek, İstasyon Caddesi Leq(63.7) 6.0 dBA yüksek seviyelerde ölçülmüştür. Ö.K.Morgül., H.Dal (2012)., Sakarya ilinde yaptıkları çalışmalarında, şehir merkezinde trafiğin yoğun olduğu kavşak ve ana yollar üzerinde 38 faklı bölgede, gürültü ölçümü için belirli noktalar seçmişlerdir. Bu çalışmalarında, hafta içi gürültü düzeylerinin ölçüm noktalarına göre değişimini, hafta içi günlerde yaklaşık Leq 60-80 dBA aralığında diğer birçok noktanın gürültü düzeyini ise Leq 65 dBA'nın üzerinde olduğunu belirlemişlerdir [22]. 
Bu çalışmada Atatürk Caddesinde Leq 60 dBA için 17.6 dBA yüksek düzeylerde iken 80 dBA için 3.0 dBA düşük seviyelerde ölçülmüştür. Mustafa Kemal Caddesi için Leq (60) 16.0 dBA yüksek iken Leq(80) için 4.0 dBA düşük. Mehmet Varinli Caddesi için Leq(60) 13.0 dBA yüksek, Leq(80) 7.0 d BAŞ düşük. Ziya Paşa Caddesi için Leq(60) 15.2 dBA yüksek, Leq(80) için 4.6 dBA düşük. Mehmet Paşa Caddesinde Leq(60) için 19.6 dBA yüksek iken Leq(80)'de 12.2 dBA daha düşük, İstasyon Caddesi Leq(60) $9.7 \mathrm{dBA}$ yüksek iken Leq(80) için 10.3 dBA daha düşük seviyelerde ölçülmüştür. Bu çalışma için önemli sayılabilecek bir diğer bulgu ise; ölçüm ve değerlendirmeler sonucu elde edilen bulgular yardımıyla kriterler arası çelişkilerin ortaya konulabilmesidir. Ölçüm ve değerlendirme çalışması yapılan lokasyonlarda standartlarla belirlenmiş olan kriterlerin çoğunun sağlanamadığı görülmektedir. (Tablo 4).

Tablo 4. Trafik gürültüsü ölçme sonuçlarının ölçütlerle karşılaştırılması

(Table 4. Comparison of traffic noise measurement results with

\begin{tabular}{|c|c|c|c|c|c|c|}
\hline BÖLGE & $\begin{array}{l}\text { LNP : } \\
62-74\end{array}$ & $\begin{array}{l}\text { L90: } \\
63 \mathrm{dBA}\end{array}$ & $\begin{array}{l}\text { TNI: } \\
74 \mathrm{dBA}\end{array}$ & $\begin{array}{l}\text { L10: } \\
70 \mathrm{dBA}\end{array}$ & $\begin{array}{l}\operatorname{Leq}_{(18)}: 55 \\
\mathrm{dBA}\end{array}$ & $\begin{array}{l}\text { L50: } \\
85 \mathrm{dBA}\end{array}$ \\
\hline Atatürk Caddesi & $\begin{array}{l}77.4 \\
{[-]}\end{array}$ & $\begin{array}{l}73.5 \\
{[-]}\end{array}$ & $\begin{array}{l}68.6 \\
{[+]}\end{array}$ & $\begin{array}{l}83.4 \\
{[-]}\end{array}$ & $\begin{array}{l}74.4 \\
{[-]}\end{array}$ & $\begin{array}{l}73.9 \\
{[+]}\end{array}$ \\
\hline $\begin{array}{l}\text { Mustafa Kemal } \\
\text { Paşa Caddesi }\end{array}$ & $\begin{array}{l}78.8 \\
{[-]}\end{array}$ & $\begin{array}{l}72.9 \\
{[-]}\end{array}$ & $\begin{array}{l}67.4 \\
{[+]} \\
\end{array}$ & $\begin{array}{l}87.1 \\
{[-]}\end{array}$ & $\begin{array}{l}76.0 \\
{[-]}\end{array}$ & $\begin{array}{l}83.4 \\
{[+]}\end{array}$ \\
\hline $\begin{array}{l}\text { Mehmet Varinli } \\
\text { Caddesi }\end{array}$ & $\begin{array}{l}75.3 \\
{[-]}\end{array}$ & $\begin{array}{l}71.0 \\
{[-]}\end{array}$ & $\begin{array}{l}68.0 \\
{[+]}\end{array}$ & $\begin{array}{l}71.7 \\
{[-]}\end{array}$ & $\begin{array}{l}73.0 \\
{[-]}\end{array}$ & $\begin{array}{l}66.8 \\
{[+]}\end{array}$ \\
\hline $\begin{array}{l}\text { Ziya Paşa } \\
\text { Bulvarı }\end{array}$ & $\begin{array}{l}77.5 \\
{[-]}\end{array}$ & $\begin{array}{l}73.0 \\
{[-]}\end{array}$ & $\begin{array}{l}69.6 \\
{[+]}\end{array}$ & $\begin{array}{l}83.5 \\
{[-]}\end{array}$ & $\begin{array}{l}75.2 \\
{[-]}\end{array}$ & $\begin{array}{l}71.3 \\
{[+]}\end{array}$ \\
\hline $\begin{array}{l}\text { Mehmet Paşa } \\
\text { Caddesi }\end{array}$ & $\begin{array}{l}81.5 \\
{[-]}\end{array}$ & $\begin{array}{l}78.2 \\
{[-]}\end{array}$ & $\begin{array}{l}75.8 \\
{[-]}\end{array}$ & $\begin{array}{l}85.9 \\
{[-]}\end{array}$ & $\begin{array}{l}79.6 \\
{[-]}\end{array}$ & $\begin{array}{l}67.8 \\
{[+]}\end{array}$ \\
\hline $\begin{array}{l}\text { İstasyon } \\
\text { Caddesi }\end{array}$ & $\begin{array}{l}72.7 \\
{[+]}\end{array}$ & $\begin{array}{l}68.5 \\
{[-]}\end{array}$ & $\begin{array}{l}64.9 \\
{[+]}\end{array}$ & $\begin{array}{l}77.0 \\
{[-]}\end{array}$ & $\begin{array}{l}70.1 \\
{[-]}\end{array}$ & $\begin{array}{l}66.1 \\
{[+]}\end{array}$ \\
\hline
\end{tabular}

Bu çalışmada seçilen bölgeler, bütünsel olarak konut ve ticaret bölgeleri olup, bu bölgeler içerisinden geçen trafik yollarına ilişkin gürültü indislerinin, kabul edilmiş olan gürültü ölçütleri ile karşılaştırması araştırılmış ve incelenen bölgelerde değişen kriterlerin veya sınır değerlerin aşıldığı durumlar belirtilmiştir.

Ölçüm ve değerlendirme sonucunda, Amasya şehir merkezinde belirlenen çoğu noktanın maksimum gürültü düzeylerinin, sabah, akşam ve gece ölçüm zaman dilimlerinde, 65 dBA (Çevresel gürültünün değerlendirilmesi ve yönetimi yönetmeliği) ve 55 dBA'yı (World Health Organization- WHO) aştığı görülmüştür [23].

İncelenen bölgelerde kriterlerin çoğunun sağlanamadığı görülmektedir. Gürültü ölçümü yapılan bölgelerde; trafik koşulları gürültü düzeyleri, yol genişlikleri, bina yükseklikleri ve konumları yönüyle benzerlikler göstermektedir. Bölgelerdeki yolların tamamında iki taraflı binaların yer almaları kanyon etkisi yaratmakta, kırılma ve yansımalara neden olmaktadır.

Amasya Kent merkezinde ana trafik yollarında yapılan ölçümlerde, çalışma yapılan caddelerin hepsinde trafik gürültüsünün 65 dBA'yı aştığı görülmüştür. Çalışmadan elde edilen bulgulara göre trafik gürültüsünün azaltılmasına yönelik çalışmaların en kısa zamanda başlatılması gerekmektedir. Bu çalışmada, ölçümlerle belirlenen seviyelerdeki gürültünün insan sağlığı açısından zararlı olması nedeniyle, trafik gürültüsünün azaltılabilmesi için alınabilecek önlemler şu şekilde önerilmektedir: 
- Amasya kent merkezinde bulunan mevcut yapılaşma oldukça çarpık ve olumsuz bir durumdadır. Mevcut binalarda ses yalıtımı yapılmamıştır. Yerel yönetimce binalarda ses yalıtımını sağlayacak malzemelerin kullanılması kontrol edilmelidir.

- Kent merkezinde kavşak ve yollar üzerinde trafik sinyalizasyonu ile ilgili gerekli noktalarda ışıklarının olmaması sebebiyle trafik kompozisyonu günün hemen her saatinde duraklı olmakta özellikle sabah ve akşam saatlerinde trafik yoğunluğu nedeniyle sıkışmakta ve araçlar gürültüye sebep olmaktadır.

- Teknik yetersizliği olan, aşırı gürültü çıkaran araçların bakımdan geçirilmesi ve yüksek gürültü düzeyine sebep olan araçlara susturucu takılması gürültünün kontrol altına alınmasında etkili olacaktır.

- Kentte; mevcut hali ile yetersiz otopark alanları çok büyük boyutlara ulaşmış olan ve otopark sorunu araçların yol kenarlarına park etmeleri sonucunda trafik sıkışıklığı hat noktalara ulaşmakta ve bu durum trafik akışındaki kompozisyonu olumsuz yönde etkileyerek gürültüye sebebiyet vermektedir. Bu nedenle yerel yönetimce hat noktalara ulaşmış olan otopark sorunu için acil çözümlerin üretilmesi gerekmektedir.

- Karayolun taşımacılığının günden güne artması, çeşitıi kara nakil vasıtalarının büyük ölçüde kullanılması, trafik gürültüsünün şiddetini arttırmaktadır. Her araç farklı seviye de gürültü meydana getirmekte ve sebep oldukları gürültüler o caddenin trafik gürültüsü düzeyini önemli ölçüde etkilemektedir.

- Şehirlerarasi otobüs terminali Mehmet Varinli Caddesi üzerinde ve yerleşim bölgesinin içine yapılmıştır. Bu durum büyük otobüslerin şehre girmesine dolayısıyla gürültünün artmasına sebep olmaktadır Şehirlerarası Otobüs terminali için kent merkezi dışında bir alanda çözüm üretilmesi kent trafiğini rahatlatacaktır.

- Gürültü değerlerini etkileyen önemli faktörler şehir merkezinde tüm ana arter ve yollarında trafik, yetersiz yol koşulları ve trafik kompozisyonu boyutu ile günün her saati için süreklilik arz etmediği gözlemlenmiştir. Trafik akışı duraklı ve akış sık sık kesintiye uğramaktadır.

- Kent içi trafik yolları ve kavşaklarında sinyalizasyon eksikliği ve mevcut trafik lambalarının ise arızalı oluşu, beraberinde yol kullanıcılarını ve sürücüleri düzensiz duruş ve kalkışlar ile trafik kurallarına uymamayı alışkanlık haline getirmeleri önemli bir etken olmaktadır. Ölçümlerde belediye toplu taşıma araçları ile alternatif yol güzergahları olmadığı için, şehirlerarası trafik yükünü taşıyan Atatürk caddesi, Mustafa Kemal caddesi ve Mehmet Varinli caddeleri üzerinden şehir merkezine kontrolsüz giren ağır vasıtaların kent içi trafik gürültü seviyesini 85-86 dBA'e kadar çıkardığı görülmüştür. Bu tür araçların 8 dBA, motorsikletler ile 3 tekerli motorların 10 dBA'llk bir gürültü artışına yol açtı̆̆ı tespit edilmiştir.

- Kent içinde ölçüm yapılan merkezlerde, mimari özelliğin oluşan gürültüyü direkt etkilediği ortaya konmuş ve bütün bölgelerde 65 dBA'lık sınırın aşıldığı belirlenmiştir. Genelde gürültüye kaynak teşkil eden birimler; başta taşıtlar olmak üzere, mimari hatalar, izolasyona uygun olmayan bina yapi malzemelerinin kullanımı, korna, müzik sesi, bazı bölgelerde iş alanlarından kaynaklanan havalandırma, darbe gürültüsü şeklinde gelen makine gibi gürültülerin yanında proje ya da malzeme seçimi ve uygulama hatası diyebileceğimiz karayollarının zemininden kaynaklanan 
gürültüler sayılabilir.

- Her ne kadar önerilen önlemler gürültü seviyesinin büyük bir oranda (30-40 dBA) azalması için yeterli olmasa da ortalama 5-20 dBA'lık bir azalma sağlanabileceği öngörülmektedir. Elde edilecek averaj, gürültü seviyesinin standart ve yönetmeliklerde öngörülen seviyenin altına indirilmesi için yeterli olacaktır.

- Gürültü seviyesi ölçüm ve değerlendirmelerinin yapıldığı bölgelerdeki yol yüzey kaplamalarının yer yer bozulmuş olduğu veya yol yüzey kaplamalarının onarım amaçlı taraklanmış olduğu saptanmıştır. Ziya Paşa Bulvarının kısmen beton kaplama oluşu yolu kullanan araçların lastiklerinin yol ile sürtünmelerinden doğan seslerin artmasına neden olduğu ve ayrıca araçların fenni bakım durumları ile egzost seslerinin de gürültü düzeylerini olumsuz yönde etkilediği saptanmıştır.

- Ayrıca; özellikle şehir merkezlerinde, trafikten kaynaklanan gürültünün, modern hayata verdiği olumsuz etkiler nedeniyle gürültü seviyelerinin azaltılması ve kontrol altına alınabilmesi çalışmaları büyük önem kazanmıştır. Bu çalışmalardan ilki gürültü haritasının oluşturulmasıdır. Gürültü haritası, şehrin şimdiki gürültü durumunu ve gürültü seviyesinin maksimum olduğu yerleri gösterir. Gürültü haritaları, şehir gelişimini belirlemede, trafik ve yol planlamalarında ve ölçülen gürültü seviyelerinin azaltılmasına yönelik çalışmalarda karar verebilmek için önemli bir destek aracıdır. "Çevresel Gürültünün Değerlendirilmesi ve Yönetimi Yönetmeliği" uyarınca gürültü kaynağı işletmecilerinin ve yerel yönetimlerin gürültü haritası hazırlaması zorunlu hale gelmiştir. Gürültü haritaları ile önceki veya öngörülen gürültü durumu, sınır değerler, gürültü değerlerine göre maruz kalınan belirli bir alandaki konut, okul ve hastanelerin tahmini sayısı ve gürültüye maruz kalınan alandaki tahmini insan sayısı gibi bilgiler verilir. Bu bilgiler, coğrafi paftalar, çizelgeler, elektronik formatta rakamsal veriler ile kamuoyuna sunulabilmektedir. Bu çalışmadan elde edilen bulgu ve verilerin ışığında Amasya kentinin gürültü haritasının hazırlanması için gerekli çalışmalar yapılarak eylem planları hazırlanmalıdır.

- Düğün, tanıtım vb. konvoylar için araç ve zaman sınırının getirilmesi gerekmektedir.

- Kent merkezinde kavşak ve yollar üzerinde trafik sinyalizasyonu ile ilgili gerekli noktalarda ışıklarının olmaması sebebiyle trafik kompozisyonu günün hemen her saatinde duraklı olmakta özellikle sabah ve akşam saatlerinde trafik yoğunluğu nedeniyle sıkışmakta ve araçlar gürültüye sebep olmaktadır. Teknik yetersizliği olan, aşırı gürültü çıkaran araçların bakımdan geçirilmesi ve yüksek gürültü düzeyine sebep olan araçlara susturucu takılması gürültünün kontrol altına alınmasında etkili olacaktır.

- Kentte; mevcut hali ile yetersiz otopark alanları çok büyük boyutlara ulaşmış olan ve otopark sorunu araçların yol kenarlarına park etmeleri sonucunda trafik sıkışıklığı hat noktalara ulaşmakta ve bu durum trafik akışındaki kompozisyonu olumsuz yönde etkileyerek gürültüye sebebiyet vermektedir. Bu nedenle yerel yönetimce hat noktalara ulaşmış olan otopark sorunu için acil çözümlerin üretilmesi gerekmektedir.

- Karayolu taşımacılığının günden güne artması, çeşitli kara nakil vasıtalarının büyük ölçüde kullanılması, trafik gürültüsünün şiddetini arttırmaktadır. Her araç farklı seviyede gürültü meydana getirmekte ve sebep oldukları gürültüler o caddenin 
trafik gürültüsü düzeyini önemli ölçüde etkilemektedir. Bunun için pek çok sanayileşmiş ülkede trafik gürültüsünü kontrol edecek ve düzeltecek idari tedbirler alınmıştır[23].

- Gürültü değerlerini etkileyen önemli faktörler şehir merkezinde tüm ana arter ve yollarında trafik, yetersiz yol koşulları ve trafik kompozisyonu boyutu ile günün her saati için süreklilik arz etmemekte, duraklı ve akış sık sık kesintiye uğramaktadır. Kent içi trafik yolları ve kavşaklarında sinyalizasyon eksikliği ve mevcut trafik lambalarının ise arızalı oluşu, beraberinde yol kullanıcılarını ve sürücüleri düzensiz duruş ve kalkışlar ile trafik kurallarına uymamay itiyat ve alışanlık haline getirmeleri önemli bir etken olmaktadır.

- Şehirde ölçüm yapılan merkezlerde, mimari özelliğin oluşan gürültüyü direkt etkilediği ortaya konmuş ve bütün bölgelerde 65 dBA'lık sınırın aşıldığı belirlenmiştir. Genel de gürültüye kaynak teşkil eden birimler; başta taşıtlar olmak üzere, mimari hatalar, izolâsyona uygun olmayan bina yapı malzemelerinin kullanımı, korna, müzik sesi, bazı bölgelerde iş alanlarından kaynaklanan havalandırma, darbe gürültüsü şeklinde gelen makine gibi gürültülerin yanında proje ya da malzeme seçimi ve uygulama hatası diyebileceğimiz karayollarının zemininden kaynaklanan gürültüler sayılabilir.

- Önerilen çözümlerin günlük hayata en kısa zamanda ve yeterince geçirilmesi gereklidir.

- Toplumun sağlığı üzerinde etkileri giderek artan gürültü kirliliği ve tehlikeleri konusunda toplumun bilinçlendirilmesi gerekmektedir. Kirlilik sorunlarının tümünde olduğu gibi, sorunun çözümü eğitim ve yönetimden geçmektedir. Daha temiz ve sağlıklı bir kent yaşamının oluşturulması için bu konuda yapılacak bilimsel araştırmaların arttırılması akademik çevreler ve yerel yönetimlerce desteklenmesi önem taşımaktadır.

- Her ne kadar önerilen önlemler gürültü seviyesinin büyük bir oranda (30-40 dBA) azalması için yeterli olmasa da ortalama 5-20 dBA'lık bir azalma sağlanabileceği öngörülmektedir. Elde edilecek averaj, gürültü seviyesinin standart ve yönetmeliklerde öngörülen seviyenin altına indirilmesi için yeterli olacaktır.

- Incelenen bölgelerde belirlenmiş olan geçerli gürültü koşullarının niceleyici değerlerinin ortaya konulduğu araştırmada saptanan gürültü düzeylerinin günlük ortalama trafik hacmi ile oldukça iyi ilişki olduğu bulunmuştur. Bu bulgular yeni bir çalışmanın konusu olabilecek özelliktedir. Özellikle gürültü bölgelerinin seçilmesi ile varılan sonuçlar yapılacak diğer çalışmalarda, daha düşük gürültü düzeylerine sahip, ana caddelere bağlanan tali yollar veya ana yollardan uzak noktalar için yapılacak çalışmalar ile bütünleştirilmelidir. Böylece trafik hacim ve koşullarının neden olduğu gürültünün işitsel konfor koşullarını ne yönde etkilediği özellikle konutlarda rastlanabilen genel fiziksel ve sosyal çevre sorunlarının ortaya konulabilecek ve bina içi gürültü sorunu ayrıca değerlendirilebilecektir.

- Önerilen çözümlerin günlük hayata en kısa zamanda ve yeterince geçirilmesi gereklidir.

Amasya'da trafik gürültüsü koşullarının saptanması ve gürültü denetimine ilişkin ölçütlerinin belirlenmesi amacıyla gerçekleştirilen araştırmanın, özellikle şehircilik ve mimarlık yönlerinden gürültü kontrolü konusunda getireceği düşünülen katkılarına işaret edilecek olursa, Çevresel gürültü konusunda yapllacak gerek bilimsel ve gerekse uygulamalı çalışmalar için ülkemiz koşullarında sağlıklı verilerin 
düzenli bir şekilde derlenmediği ve verilerin bulunmadığı düşünülürse gerçekleştirilen bu araştırma bu yönüyle değer ve önem taşımaktadır.

\section{NOT (NOTE)}

Bu çalışmada destek ve yardımlarını aldığım, çalışma arkadaşım Yrd.Doç.Dr Okan M. Dede ve değerli arkadaşım Serdar Kaygusuz'a teşekkürü bir borç bilirim.

\section{KAYNAKLAR (REFERENCES)}

1. Pierrer, S., Valcke, E.D., and Cluydts, R., (2010). Night traffic noise on sleep and health assessment and a review of the results. Environment International 36 (5), 492-498 CrossRef.

2. Aktürk, N. ve Gürpınar, M., (2001). "Çevresel Ulaşım Gürültüsünün Trafik Planlaması Yönünden İncelenmesi" Trafik ve Yol Güvenliği Kongresi, Gazi Üniversitesi, Ankara 346-359.

3. Kumbur, H., Özsoy, H.D. ve Özer, Z., (2003). "Mersin İlinde Hassas bölgelerde Gürültü Düzeylerinin 1998-2002 Yılları Arasındaki Değişiminin Araştırılması "Ekoloji Çevre Dergisi, Cilt 13, Sayı $49,25-30$,

4. Nas, B., (2004). Konya Kenti Yol Trafik Gürültüsü Seviyelerinin Coğrafi Bilgi Sistemleri (CBS) ile Görüntülenmesi, bilgi Sistemleri Bileşim Günleri, 6-9 Ekim, 2004

5. Aydın, M.E. ve Ateş N., (1997). Konya'da Trafik Gürültüsü ve Bazi Öneriler Pamukkale Üniversitesi Mühendislik Bilimleri Dergisi Journal of Engineering Science cilt:3 Sayı:3 447-456

6. Gezbul, H. ve Öz, N.,(1996). Sakarya İlinde Trafik Kaynaklı Gürültü ve Kontrolü Sakarya Üniversitesi. Fen Bilimleri Enstitüsü Dergisi, Cilt: 2 Sayı: 1

7. Özer, S., Yılmaz, H., Yeşil, M. ve Yeşil P., (2009). Evaluation of noise pollution caused by vehicles in the city of Tokat Turkey", Scientific Research Essays, Vol. 4 (11), p. 1205-1212

8. Şahin, K., (2012). Samsun (Atakum) Şehrinde Çevresel Gürültü Kirliliği Uluslararası Sosyal Araştırmalar Dergisi The Journal of International Social Research, Cilt: 7 Sayl: 29 Volume:

9. A.Piccolo, D., Plutino, G., and Cannistraro.,(2005). Evaluation and analysis of the Applied Acoustics environmental noise of Messina, Italy Volume 66, Issue 4, April 2005, Pages 447-46.

10. Bendtsen, H., (1999). The Nordic prediction method for road traffic noise Science of The Total Environment Volume 235, September Pages 331-338.

11. Güremen, L. ve Çelik, C.T., (2002). Niğde Şehir Merkezinde Trafik Gürültüsü Kirliliğinin Belirlenmesi Niğde Üniversitesi Mühendislik Bilimleri Dergisi Cilt. 6 Sayı.,1-2 s17-22.

12. A.Piccolo, A., Plutino, D., and Cannistraro, G., (2005). Evaluation and analysis of the Applied Acoustics environmental noise of Messina Italy Volume 66, Issue 4, April 2005, Pages 447465 .

13. Nijland, H.A. and Van Wee, G.P., (2005). Traffic Noise in Europe: A Comparison of Calculation Methods, Noise Indices and Noise Standards for Road and Railroad Traffic in Europe Transport Reviews: A Transnational Transdisciplinary Journal Volume 25, Issue 5, 2005 pages 591-612.

14. Anon., (1975). "Statistical Noise Level Analysis and Leq Measurement", Brüel\&Kjaer, Report, Gambart R., Myncke H., Cops A., "Study of annoyance of Traffic Noise in Leuven (Belgium)", App.Ac. v.9, n3, s.193, 1976.

15. Zannin, P.H.T., Diniz, F.B.R. and Barbosa, W.A.., (2002). "Environmental noise pollution in the city of Curritiba, Brazil" Applied Acoustics, 63, 351-358, . 
16. Türkiye İstatistik Kurumu (TÜIK), 2014 verilerine göre İlere Göre Taşıt Sayıları.

17. Olayinka, O.S., (2013). Effective Noise Control Measures and Sustainable Development in Nigeria World Journal of Environmental Engineering., $1(1), 5-15$ http://pubs.sciepub.com/wjee/1/1/2/index.html.

18. Doi, L., Caol, J., Fan, L., and Mobed, N., (2005). Traffic Noise Evaluation and Analysis in Residential Areas of Regina Journal of Environmental Informatics 5 (1) 17-25.

19. Gupta, S. and Ghatak, C., (2011). "Enviromental noise assessment and its effect on human health in an urban " International Journal of environmental sciences volume 1, no 7.

20. Tosun, I., Avşar, Y., Sevindir, H. ve Beyhan, M., (2013). "Isparta'da Gürültü Düzeyi Üzerine Trafik, Endüstri ve Ticari faaliyetlerin Etkisi" S.D.Ü Fen Bilimleri Enstitüsü Dergisi cilt 16. sayl 2, s.83-91.

21. Morgül, Ö.K. ve Dal, H., (2012). Sakarya İli Şehir Merkezinin Gürültü Kirliliği Üzerine Bir Ön Çalışma SAÜ. Fen Bilimleri Dergisi, 16. Cilt, 2. Sayı, s. 83-91.

22. National Reserarch Council, (1973). Noise Abatement and Control, Highway Reserarch Record No. 448, Highway Reserarch Board, Washington. 